\title{
Working
}

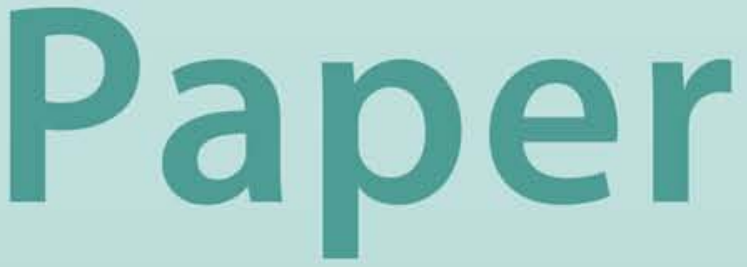


Resolution of Banking Crises:

The Good, the Bad, and the Ugly

Luc Laeven and Fabian Valencia 


\title{
IMF Working Paper
}

Research Department

\section{Resolution of Banking Crises: The Good, the Bad, and the Ugly}

\author{
Prepared by Luc Laeven and Fabian Valencia ${ }^{1}$
}

Authorized for distribution by Stijn Claessens

June 2010

\begin{abstract}
This Working Paper should not be reported as representing the views of the IMF. The views expressed in this Working Paper are those of the author(s) and do not necessarily represent those of the IMF or IMF policy. Working Papers describe research in progress by the author(s) and are published to elicit comments and to further debate.
\end{abstract}

This paper presents a new database of systemic banking crises for the period 1970-2009. While there are many commonalities between recent and past crises, both in terms of underlying causes and policy responses, there are some important differences in terms of the scale and scope of interventions. Direct fiscal costs to support the financial sector were smaller this time as a consequence of swift policy action and significant indirect support from expansionary monetary and fiscal policy, the widespread use of guarantees on liabilities, and direct purchases of assets. While these policies have reduced the real impact of the current crisis, they have increased the burden of public debt and the size of government contingent liabilities, raising concerns about fiscal sustainability in some countries.

\section{JEL Classification Numbers:E50; E60; G20}

Keywords: banking crisis; government intervention; crisis resolution; macroeconomic policy

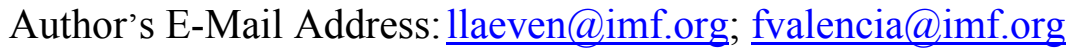

\footnotetext{
${ }^{1}$ Luc Laeven is Deputy Division Chief in the Research Department of the International Monetary Fund and Research Fellow at CEPR, and Fabian Valencia is Economist in the Research Department of the International Monetary Fund. The authors thank Eugenio Cerutti, Stijn Claessens, Luis Cortavarria-Checkley, Peter Dohlman, Mark Griffiths, Aditya Narain, David Parker, Noel Sacasa, and Johannes Wiegand, for comments and/or discussions, and Jeanne Verrier for outstanding research assistance.
} 


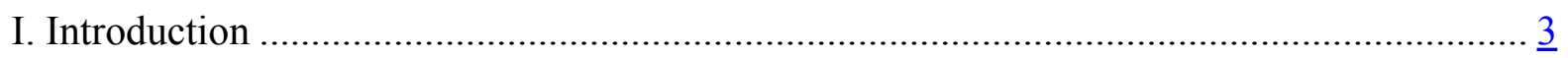

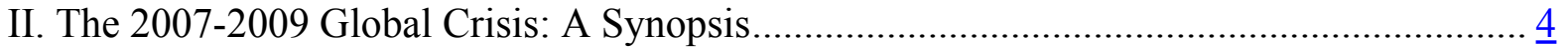

III. Which Countries Had a Systemic Banking Crisis in 2007-2009? .................................. $\underline{6}$

IV. Policy Responses in the 2007-2009 Crises: What Is New? ....................................... 12

V. How Costly Are the 2007-2009 Systemic Banking Crises? ......................................... 22

VI. Concluding Remarks ..................................................................................... 27

Box

1. U.S. Bank Failures: Past and Present ................................................................ 19

Table

1. Systemic Banking Crises, 2007-2009........................................

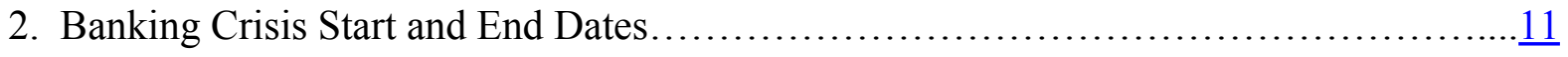

3. Market Capitalization of Top 30 Banks Worldwide, by Nationality.....................

4. Summary of the Cost of Banking Crises.............................................

A.1. Systemic Banking Crises Policy Responses.................................

A.2. Preemptive Responses in Selected G-20 Countries.................................................

A.3. Direct Fiscal Outlays, Recoveries to Date, and Asset Guarantees........................ $\underline{33}$

A.4. Top 30 Banks in the World By Market Capitalization............................. $\underline{35}$

Figures

1. Foreign Claims by Nationality of Reporting Banks...............................13

2. Emergency Central Bank Liquidity Support....................................14

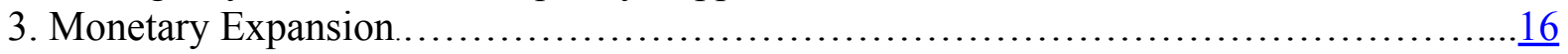

4. Timing of Recapitalization Policies...........................................

5. Bank Failures and Interventions in Selected Countries...............................18

6. U.S. Bank Failures: Fraction of Failed Banks.................................... 19

7. U.S. Bank Failures: Market Share of Failed Banks..................................... $\frac{19}{20}$

8. U.S. Bank Failures: Loss Rates on Assets of Failed Banks............................... $\frac{20}{23}$

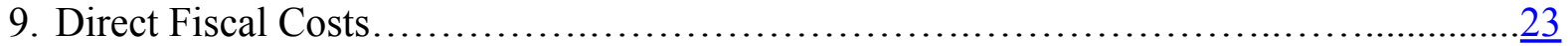

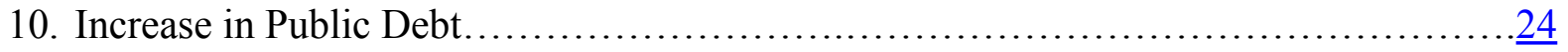

11. Increase in Public Debt and Direct Fiscal Costs............................... $\frac{25}{26}$

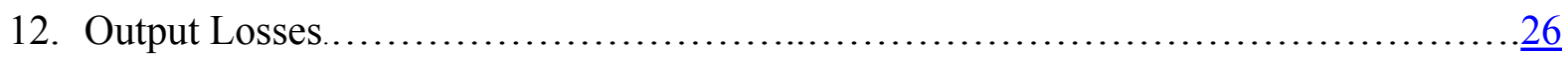




\section{INTRODUCTION}

Since 2007, the world has experienced a period of severe financial stress, not seen since the time of the Great Depression. This crisis started with the collapse of the subprime residential mortgage market in the United States and spread to the rest of the world through exposure to U.S. real estate assets, often in the form of complex financial derivatives, and a collapse in global trade. Many countries were significantly affected by these adverse shocks, causing systemic banking crises in a number of countries, despite extraordinary policy interventions.

Systemic banking crises are disruptive events not only to financial systems but to the economy as a whole. Such crises are not specific to the recent past or specific countries almost no country has avoided the experience and some have had multiple banking crises. While the banking crises of the past have differed in terms of underlying causes, triggers, and economic impact, they share many commonalities. Banking crises are often preceded by prolonged periods of high credit growth and are often associated with large imbalances in the balance sheets of the private sector, such as maturity mismatches or exchange rate risk, that ultimately translate into credit risk for the banking sector.

With the recovery from the latest crisis underway, some questions naturally arise: What caused the most recent crisis? How come this crisis led to varied levels of stress in different countries? How does the cost of this crisis compare to that of previous banking crisis episodes? And how do current policy responses differ from those of the past?

This paper presents new and comprehensive data on the starting dates and characteristics of systemic banking crises over the period 1970-2009, building on earlier work by Caprio et al. (2005), Laeven and Valencia (2008), and Reinhart and Rogoff (2009). In particular, we update the Laeven and Valencia (2008) database on systemic banking crises to include the recent episodes following the U.S. mortgage crisis of 2007. The update makes several improvements to the earlier database, including an improved definition of systemic banking crisis, the inclusion of crisis ending dates, and a broader coverage of crisis management policies. The result is the most up-to-date banking crisis database available. ${ }^{2}$

The new data show that there are many commonalities between recent and past crises, both in terms of underlying causes and policy responses, yet there are also some striking differences in the economic and fiscal costs associated with the new crises. The economic cost of the new crises is on average much larger than that of past crises, both in terms of output losses and increases in public debt. The median output loss (computed as deviations of actual output from its trend) is 25 percent of GDP in recent crises, compared to a historical median of 20 percent of GDP, while the median increase in public debt (over the three year period

\footnotetext{
${ }^{2}$ The banking crisis dataset is publicly available www.luclaeven.com/Data.htm
} 
following the start of the crisis) is 24 percent of GDP in recent crises, compared to a historical median of 16 percent of GDP. These differences in part reflect an increase in the size of financial systems, the fact that the recent crises are concentrated in high-income countries, and possibly differences in the size of the initial shock to the financial system.

At the same time, direct fiscal costs to support the financial sector were smaller this time at 5 percent of GDP, compared to 10 percent of GDP for past crises, as a consequence of relatively swift policy action and the significant indirect support the financial system received through expansionary monetary and fiscal policy, the widespread use of guarantees on liabilities, and direct purchases of assets that helped sustain asset prices.

Policy responses broadly consisted of the same type of containment and resolution tools as used in previous crisis episodes. As in past crises, policymakers used extensive liquidity support and guarantees. However, recapitalization policies were implemented more quickly this time around. The time it took policymakers to implement comprehensive recapitalization measures from the moment that liquidity support became extensive was around zero months in the recent crises, compared to

While in previous crises it took policymakers about one year from the time that liquidity support became extensive before comprehensive recapitalization measures were implemented, this time recapitalization measured were implemented around the same time that liquidity support became extensive.

While all these extraordinary measures have contributed to reduce the real impact of the recent crisis, they also have increased the burden of public debt and the size of fiscal contingent liabilities, raising concerns about fiscal sustainability in a number of countries.

The paper proceeds as follows. Section II presents a brief review of the events that led to the 2007-2009 global crises. Section III defines a systemic banking crisis and presents a list of countries that meet this definition. Section IV describes the policy responses and contrasts them with past crises. Section V presents the cost of recent crises and a comparison with past episodes. Section VI concludes.

\section{The 2007-2009 GlObal Crisis: A SYNOPSIS}

Over the decade prior to the crisis, the United States and several other advanced economies experienced an uninterrupted upward trend in real estate prices, which was particularly pronounced in residential property markets. What originated this boom is still a source of debate, though there appears to be broad agreement that financial innovation in the form of asset securitization, government policies to increase homeownership, global imbalances, expansionary monetary policy, and weak regulatory oversight played an important role (e.g., Keys et al., 2010; Obstfeld and Rogoff, 2009; and Taylor, 2009). 
The boom in real estate prices was exacerbated by financial institutions' ability to exploit loopholes in capital regulation, allowing banks to significantly increase leverage while maintaining capital requirements. They did so by moving assets off-balance sheet into special purpose vehicles that were subject to weaker capital standards and by funding themselves increasingly short-term and in wholesale markets rather than traditional deposits. These special purpose vehicles were used to invest in risky and illiquid assets (such as mortgages and mortgage derivatives) and were funded in wholesale markets (for example, through asset backed commercial paper), without the backing of adequate capital. The growing importance of this shadow banking system highly dependent on short term funding, combined with lax regulatory oversight, was a key contributor to the asset price bubble (Gorton, 2008, Brunnermeier, 2009, and Acharya and Richardson, 2009).

Higher asset prices led to a leverage cycle by which increases in home values led to increases in debt. The rise in asset prices decreased measured "value at risk" at financial institutions, creating spare capacity in their balance sheets and leading to an increase in leverage and supply of credit (Adrian and Shin, 2008). A similar mechanism took place in the household sector, as perceived household wealth increased on the back of rising home values. Easy access to the equity accumulated in their homes led households to increase their leverage substantially. Mian and Sufi (2009) estimate that the average homeowner extracted 25 to 30 cents for every dollar increase in home equity to be used in real outlays. The asset price boom was further fueled by an explosion of subprime mortgage credit in the United States starting in 2002 and reaching a peak around mid-2006 (Dell'Ariccia et al, 2008).

The first signs of distress came in early 2007 from losses at U.S. subprime loan originators and institutions holding derivatives of securitized subprime mortgages. However, these first signs were limited to problems in the subprime mortgage market. Later in 2007, these localized signs of distress turned into a global event, with losses spreading to banks in Europe (such as U.K. mortgage lender Northern Rock), and distress was no longer limited to financial institutions with exposure to the U.S. subprime mortgage market.

To alleviate liquidity shortages, the U.S. Federal Reserve reduced the penalty to banks for accessing its discount window, and later that year created the Term Auction Facility. Similarly, a blanket guarantee was issued in the United Kingdom for Northern Rock's existing deposits. Problems intensified in the United States with the bailout of Bear Stearns, and later in the year with the collapse of investment bank Lehman Brothers, and the government bailouts of insurer AIG and mortgage lenders Freddie Mac and Fannie Mae. By the end of 2007, many economies around the world suffered from a collapse in international trade, reversals in capital flows, and sizable contractions in real output. But as the crisis mounted, so did the policy responses, with many countries announcing bank recapitalization packages and other support for the financial sector in late 2008 and early 2009.

While some aspects of this crisis appear new, such as the role of asset securitization in spreading risks across the financial system, it broadly resembles earlier boom-bust episodes, 
many of which followed a period of financial liberalization. One commonality among these crises is a substantial rise in private sector indebtedness, with the infected sectors besides banks being the household sector (as in the current U.S. crisis and the Nordic crises of the nineties), the corporate sector (as in the case of the 1997-98 East Asian financial crisis), or both. As in earlier crisis episodes, asset prices rose sharply while banks decreased reliance on deposits in favor of less stable sources of wholesale funding, and while non-banking institutions (for instance, finance companies in Thailand in the nineties, and offshore financial institutions in Latin America in the eighties and nineties) grew significantly owing in part to laxer prudential requirements for non-banks.

When such crises erupt, they generally trigger losses that spread rapidly throughout the financial system by way of downward pressures on asset prices and interconnectedness among financial institutions. These broad patterns repeated themselves this time around when losses in the U.S. real estate market triggered general runs on the U.S. shadow banking system, which ultimately hit banks in the U.S and elsewhere.

\section{Which COUnTRIES HAd A Systemic BANKING CRISIS IN 2007-2009?}

The financial crisis that started in the United States in 2007 spread around the world, affecting banking systems in many other countries. In this section, we define a systemic banking crisis and identify which countries experienced one. We also identify countries that can be considered as cases of borderline banking crises, and countries that escaped a banking crisis (either because they evaded a crisis through successful policies or because they were not hit by the negative shock emanating from the United States).

We consider a banking crisis to be systemic if two conditions are met:

1) Significant signs of financial distress in the banking system (as indicated by significant bank runs, losses in the banking system, and bank liquidations); and

2) Significant banking policy intervention measures in response to significant losses in the banking system.

We consider the first year that both criteria are met to be the starting year of the banking crisis, and consider policy interventions in the banking sector to be significant if at least three out of the following six measures have been used: ${ }^{3}$

\footnotetext{
${ }^{3}$ We express, when possible, the magnitude of policy interventions and associated fiscal costs in terms of GDP rather than banking system size to control for the ability of a country's economy to support its banking system. This naturally results in higher measured fiscal costs for economies with larger banking systems.
} 
1) extensive liquidity support (5 percent of deposits and liabilities to nonresidents)

2) bank restructuring costs (at least 3 percent of GDP)

3) significant bank nationalizations

4) significant guarantees put in place

5) significant asset purchases (at least 5 percent of GDP), and

6) deposit freezes and bank holidays.

In implementing this definition of systemic interventions, we consider liquidity support to be extensive when the ratio of central bank claims on the financial sector to deposits and foreign liabilities exceeds 5 percent and more than doubles relative to its pre-crisis level. ${ }^{4}$

Direct bank restructuring costs are defined as the component of gross fiscal outlays directing to restructuring the financial sector, such as recapitalization costs. They exclude asset purchases and direct liquidity assistance from the treasury. We define significant direct restructuring costs as those exceeding 3 percent of GDP.

Asset purchases from financial institutions include those implemented through the treasury or the central bank. We define significant asset purchases as those exceeding 5 percent of GDP. ${ }^{5}$

A significant guarantee on bank liabilities indicates that either a full protection of liabilities has been issued or that guarantees have been extended to non-deposit liabilities of banks. ${ }^{6}$ Actions that only raise the level of deposit insurance coverage are not deemed significant.

Significant nationalizations are takeovers by the government of systemically important financial institutions and include cases where the government takes a majority stake in the capital of such financial institutions.

\footnotetext{
${ }^{4}$ We exclude domestic non-deposit liabilities from the denominator of this ratio because information on such liabilities is not readily available on a gross basis. For Euro-area countries, we also consider liquidity support to be extensive if in a given semester the increase in this ratio is at least 5 percentage points. The reason is that data on Euro-area central bank claims are confounded by large volumes of settlements and cross-border claims between banks in the Eurosystem. As a result, the central banks of some Euro area countries (notably Germany and Luxembourg) had already large pre-crisis levels of claims on the financial sector.

${ }^{5}$ Asset purchases also provide liquidity to the system. Therefore, an estimate of total liquidity injected would include schemes such as the Special Liquidity Scheme (185 bn pounds sterling) in the United Kingdom and Norway's Bond Exchange Scheme (230 bn kronas), as well as liquidity provided directly by the Treasury.

${ }^{6}$ Although we do not consider a quantitative threshold for this criteria, in all cases guarantees involved significant financial sector commitments relative to the size of the corresponding economies.
} 
In the past, some countries intervened in their financial sectors using a combination of less than three of these measures but on a large scale (for example, by nationalizing all major banks in the country). Therefore, we consider a sufficient condition for a crisis episode to be deemed systemic when either (i) a country's banking system exhibits significant losses resulting in a share of nonperforming loans above 20 percent or bank closures of at least 20 percent of banking system assets) or (ii) fiscal restructuring costs of the banking sector are sufficiently high exceeding 5 percent of GDP. ${ }^{7}$ For the recent wave of crises, none of these additional criteria are needed to identify systemic events.

Quantitative thresholds to implement our definition of a systemic banking crisis are admittedly arbitrary; therefore, we also maintain an additional list of "borderline cases" that almost met our definition of a systemic crisis. At the same time, our more quantitative approach is a major improvement over earlier efforts to date banking crises (such as Caprio et al., 2005; Laeven and Valencia, 2008; and Reinhart and Rogoff, 2009) that relied on a qualitative approach to determine banking crises as situations in which "a large fraction of banking system capital has been depleted".

Table 1 provides the list of countries that meet our definition during the recent episode. For each case, we also indicate the exact criteria that are met. We do not include a separate column on deposit freezes and bank holidays because no episode during this recent wave of banking crises made use of banking holidays, while deposit freezes were used only for Parex bank in Latvia. In total, we identify 13 systemic banking crises and 10 borderline cases since the year 2007. ${ }^{8}$ Table A.1 in the Appendix presents more detailed information about the policy interventions in these cases.

As in our previous crisis database release (Laeven and Valencia, 2008), the starting year of the banking crises in the United Kingdom and the United States is 2007, while for all other cases the starting date is the year $2008 .^{9}$

\footnotetext{
${ }^{7}$ One concrete historical example is Latvia's 1995 crisis, when banks totaling 40 percent of financial system's assets were closed, depositors experienced losses, but few of the interventions listed above were implemented.

${ }^{8}$ Our new definition of a systemic banking crisis is somewhat more specific than the one used in Laeven and Valencia (2008), where systemic crises were considered to include events with "significant policy interventions". As a consequence, a few cases listed as systemic banking crisis in our previous release, would under this definition be considered borderline cases: Brazil 1990, Argentina 1995, Czech Republic 1996, Philippines 1997, and United States 1988.

${ }^{9}$ While undoubtedly the most salient events of the UK and US financial crises took place in 2008 (such as the bailout of Bear Stearns, the collapse of Lehman Brothers, the takeover of the GSEs, and the TARP programs in the US; and the nationalization of the Royal Bank of Scotland in the UK), significant signs of financial sector distress and policy actions directed to the financial sector were in both cases already observed in 2007 .
} 
Table 1. Systemic Banking Crises, 2007-2009

\begin{tabular}{|c|c|c|c|c|c|}
\hline Country & $\begin{array}{c}\text { Extensive } \\
\text { Liquidity } \\
\text { Support }\end{array}$ & $\begin{array}{c}\text { Significant } \\
\text { Restructuring } \\
\text { Costs }\end{array}$ & $\begin{array}{c}\text { Significant } \\
\text { Asset } \\
\text { Purchases }\end{array}$ & $\begin{array}{c}\text { Significant } \\
\text { Guarantees } \\
\text { on Liabilities }\end{array}$ & $\begin{array}{c}\text { Significant } \\
\text { Nationalizations }\end{array}$ \\
\hline
\end{tabular}

\begin{tabular}{|c|c|c|c|c|c|}
\hline \multicolumn{6}{|c|}{ Systemic Cases } \\
\hline Austria & $\checkmark$ & & & $\checkmark$ & $\checkmark$ \\
\hline Belgium & $\checkmark$ & $\checkmark$ & & $\checkmark$ & $\checkmark$ \\
\hline Denmark & $\checkmark$ & & & $\checkmark$ & $\sqrt{ }$ \\
\hline Germany & $\checkmark$ & & & $\checkmark$ & $\checkmark$ \\
\hline Iceland & $\checkmark$ & $\checkmark$ & & $\checkmark$ & $\checkmark$ \\
\hline Ireland & $\checkmark$ & $\checkmark$ & & $\checkmark$ & $\checkmark$ \\
\hline Latvia & $\checkmark$ & & & $\checkmark$ & $\checkmark$ \\
\hline Luxembourg & $\checkmark$ & $\checkmark$ & & $\checkmark$ & $\checkmark$ \\
\hline Mongolia & $\checkmark$ & $\checkmark$ & & $\checkmark$ & $\checkmark$ \\
\hline Netherlands & $\checkmark$ & $\checkmark$ & & $\checkmark$ & $\checkmark$ \\
\hline Ukraine & $\checkmark$ & $\checkmark$ & & & $\checkmark$ \\
\hline United Kingdom & $\checkmark$ & $\checkmark$ & $\checkmark$ & $\checkmark$ & $\checkmark$ \\
\hline United States & $\checkmark$ & $\checkmark$ & $\checkmark$ & $\checkmark$ & $\checkmark$ \\
\hline \multicolumn{6}{|c|}{ Borderline Cases } \\
\hline France & $\checkmark$ & & & $\checkmark$ & \\
\hline Greece & $\checkmark$ & & & $\checkmark$ & \\
\hline Hungary & $\checkmark$ & & & $\checkmark$ & \\
\hline Kazakhstan & $\checkmark$ & $\checkmark$ & & & \\
\hline Portugal & $\checkmark$ & & & $\checkmark$ & \\
\hline Russia & $\checkmark$ & & & $\checkmark$ & \\
\hline Slovenia & $\checkmark$ & & & $\checkmark$ & \\
\hline Spain & $\checkmark$ & & & $\checkmark$ & \\
\hline Sweden & $\checkmark$ & & & $\checkmark$ & \\
\hline Switzerland & $\checkmark$ & & $\checkmark$ & & \\
\hline
\end{tabular}

Note: Systemic banking crises are defined as cases where at least three of the listed interventions took place, whereas borderline cases are those that almost met our definition of a systemic crisis. Extensive liquidity support is defined as a situation where central bank claims on the financial sector exceed 5 percent of deposits and foreign liabilities and is at least twice as large as pre-crisis levels; direct bank restructuring costs are considered significant when they exceed 3 percent of GDP and exclude liquidity and asset purchase outlays; guarantees on liabilities are considered significant when they include actions that guarantee liabilities of financial institutions other than just increasing deposit insurance coverage limits; nationalizations are significant when they affect systemic financial institutions.

Source: Authors' calculations. 
Most policy packages announced in countries that do not meet our definition can be seen as pre-emptive interventions. In a large subset of G-20 countries, direct policies to support the financial sector were quite modest. For instance, Argentina, Brazil, China, India, Indonesia, Mexico, Saudi Arabia, South Africa, and Turkey all did not announce direct financial sector support measures that involved fiscal outlays. Some did issue or increase guarantees on bank liabilities, creating contingent liabilities for the government. For example, Mexico announced a guarantee on commercial paper up to a limit of 50 billion pesos. Other G-20 countries were more seriously affected by the financial turmoil and reacted more strongly, but ultimately did not intervene at a large enough scale to be deemed a systemic crisis. Appendix Table A.2 provides more details about these cases, including the actual usage of policy measures. The differences between announced and actually used amounts are quite striking in a number of cases, with the actual usage of announced packages on average being small (see also Cheasty and Das (2009) for a comparison between announcements and used amounts).

In Laeven and Valencia (2008), we included only the first year of the crisis but did not report an end date for the crisis episode. We now expand our previous release by dating the end of each episode. We define the end of a crisis as the year before two conditions hold: real GDP growth and real credit growth are positive for at least two consecutive years. In case the first two years record growth in real GDP and real credit, the crisis is dated to end the same year it starts. ${ }^{10}$ Admittedly, this is an oversimplification given the many factors that come into play in a crisis, and the different nature of crisis and recoveries across our sample. In a number of cases this methodology results in long crisis durations, which sometimes is the consequence of additional shocks affecting the country's economic performance. In order to keep the rule simple, we truncate duration at 5 years, beginning with the crisis year. As of end-2009, none of the recent crises had ended according to the definition we use in this paper. The median duration of a crisis for our old episodes is 2 years. Start and end dates for all episodes are reported in Table 2, in which we also report output losses (to be defined in the next section).

\footnotetext{
${ }^{10}$ In computing end dates, we use bank credit to the private sector (in national currency) from IFS (line 22d). Bank credit series are deflated using CPI from WEO. GDP in constant prices (in national currency) also comes from the WEO. When credit data is not available, the end date is determined as the first year before GDP growth is positive for at least two years. In all cases, we truncate the duration of a crisis at 5 years, including the first crisis year.
} 
Table 2. Banking Crisis Start and End Dates

\begin{tabular}{|c|c|c|c|c|c|c|c|c|c|c|c|c|}
\hline Country & Start End & Output los & s Country & Start End & Output los & s Country & Start End & Output los & s Country & Start & End & Outpus loss \\
\hline $\begin{array}{l}\text { Albania 4/ } \\
\text { Algeria }\end{array}$ & $\begin{array}{l}19941994 \\
199019942 /\end{array}$ & $41 \%$ & $\begin{array}{l}\text { Congo, Rep } \\
\text { Costa Rica }\end{array}$ & $\begin{array}{l}19921994 \\
19871991\end{array}$ & $\begin{array}{c}47 \% \\
0 \%\end{array}$ & $\begin{array}{l}\text { Kazakhstan 3/ } \\
\text { Kenya }\end{array}$ & $\begin{array}{l}2008 \ldots \\
19851985\end{array}$ & $\begin{array}{c}0 \% \\
24 \%\end{array}$ & \begin{tabular}{|l} 
Romania 4/ \\
Russia 4/
\end{tabular} & $\begin{array}{l}1990 \\
1998\end{array}$ & $\begin{array}{l}19921 / \\
19981 /\end{array}$ & $0 \%$ \\
\hline Argentina & $198019821 /$ & $58 \%$ & Costa Rica & 19941995 & $0 \%$ & Kenya & 19921994 & $50 \%$ & Russia 3/ & 2008 & $\ldots$ & $0 \%$ \\
\hline Argentina & 19891991 & $13 \%$ & Croatia 4/ & 19981999 & & Korea & 19971998 & $58 \%$ & São Tomé \& Príncipe & 1992 & $19921 /$ & $2 \%$ \\
\hline Argentina $3 /$ & 19951995 & $0 \%$ & Czech Republic 3/ 4/ & / 19962000 2/ & & Kuwait & 19821985 & $143 \%$ & Senegal & 1988 & 1991 & $6 \%$ \\
\hline Argentina & 20012003 & $71 \%$ & Denmark & $2008 \ldots$ & $36 \%$ & Kyrgyz Rep 4/ & 19951999 2/ & & Sierra Leone & 1990 & $19942 /$ & $34 \%$ \\
\hline $\begin{array}{l}\text { Armenia /4 } \\
\text { Austria }\end{array}$ & $\begin{array}{l}199419941 / \\
2008 \ldots \\
199519951 /\end{array}$ & $17 \%$ & $\begin{array}{l}\text { Diibouti } \\
\text { Dominican Rep } \\
\text { Ecuador }\end{array}$ & $\begin{array}{l}19911995 \text { 2/ } \\
20032004\end{array}$ & $43 \%$ & $\begin{array}{l}\text { Latvia 4/ } \\
\text { Latvia }\end{array}$ & $\begin{array}{l}19951996 \\
2008 \ldots\end{array}$ & $116 \%$ & $\begin{array}{l}\text { Slovak Rep } \\
\text { Slovenia 4/ }\end{array}$ & $\begin{array}{l}19984 \\
1992\end{array}$ & $\begin{array}{l}20022 / \\
1992\end{array}$ & $0 \%$ \\
\hline $\begin{array}{l}\text { Azerbaijan 4/ } \\
\text { Bangladesh }\end{array}$ & $\begin{array}{l}199519951 / \\
19871987\end{array}$ & $0 \%$ & $\begin{array}{l}\text { Ecuador } \\
\text { Ecuador }\end{array}$ & $\begin{array}{l}198219862 / \\
19982002\end{array}$ & $\begin{array}{l}98 \% \\
25 \%\end{array}$ & $\begin{array}{l}\text { Lebanon } \\
\text { Liberia }\end{array}$ & $\begin{array}{l}19901993 \\
199119952 /\end{array}$ & $102 \%$ & $\begin{array}{l}\text { Slovenia 3/ } \\
\text { Spain }\end{array}$ & $\begin{array}{l}2008 \\
1977\end{array}$ & $\begin{array}{l}\cdots \\
19812 /\end{array}$ & $\begin{array}{l}37 \% \\
59 \%\end{array}$ \\
\hline $\begin{array}{l}\text { Belarus 4/ } \\
\text { Belgium }\end{array}$ & $\begin{array}{l}19951995 \\
2008 \ldots\end{array}$ & $23 \%$ & $\begin{array}{l}\text { Egvpt } \\
\text { El Salvador }\end{array}$ & $\begin{array}{l}19801980 \\
19891990\end{array}$ & $\begin{array}{l}1 \% \\
0 \%\end{array}$ & $\begin{array}{l}\text { Lithuania 4/ } \\
\text { Luxembourg }\end{array}$ & $\begin{array}{l}19951996 \\
2008 \ldots\end{array}$ & $47 \%$ & $\begin{array}{l}\text { Spain 3/ } \\
\text { Sri Lanka }\end{array}$ & $\begin{array}{l}2008 \\
1989\end{array}$ & $\begin{array}{l}\ldots \\
1991\end{array}$ & $\begin{array}{l}39 \% \\
20 \%\end{array}$ \\
\hline $\begin{array}{l}\text { Benin } \\
\text { Bolivia }\end{array}$ & $\begin{array}{l}198819922 / \\
19861986\end{array}$ & $\begin{array}{l}15 \% \\
49 \%\end{array}$ & $\begin{array}{l}\text { Equatorial Guinea } \\
\text { Eritrea }\end{array}$ & $\begin{array}{l}198319831 / \\
199319931 /\end{array}$ & $0 \%$ & $\begin{array}{l}\text { Macedonia, FYR 4/ } \\
\text { Madagascar }\end{array}$ & $\begin{array}{l}19931995 \\
19881988\end{array}$ & $\begin{array}{l}0 \% \\
0 \%\end{array}$ & $\begin{array}{l}\text { Swaziland } \\
\text { Sweden }\end{array}$ & $\begin{array}{l}1995 \\
1991\end{array}$ & $\begin{array}{l}19992 / \\
1995\end{array}$ & $\begin{array}{l}46 \% \\
33 \%\end{array}$ \\
\hline $\begin{array}{l}\text { Bolivia } \\
\text { Bosnia and Herzegovina 4/ }\end{array}$ & $\begin{array}{l}19941994 \\
199219962 /\end{array}$ & $0 \%$ & $\begin{array}{l}\text { Estonia 4/ } \\
\text { Finland }\end{array}$ & $\begin{array}{l}19921994 \\
19911995\end{array}$ & $70 \%$ & $\begin{array}{l}\text { Malavsia } \\
\text { Mali }\end{array}$ & $\begin{array}{l}19971999 \\
198719912 /\end{array}$ & $\begin{array}{c}31 \% \\
0 \%\end{array}$ & $\begin{array}{l}\text { Sweden 3/ } \\
\text { Switzerland 3/ }\end{array}$ & $\begin{array}{l}2008 \\
2008\end{array}$ & $\begin{array}{l}\ldots \\
\ldots\end{array}$ & $\begin{array}{l}31 \% \\
0 \%\end{array}$ \\
\hline $\begin{array}{l}\text { Brazil 3/ } \\
\text { Brazil } \\
\text { Bulgaria }\end{array}$ & $\begin{array}{l}199019942 / \\
19941998 \\
19961997\end{array}$ & $\begin{array}{c}62 \% \\
0 \% \\
60 \%\end{array}$ & $\begin{array}{l}\text { France 3/ } \\
\text { Georgia 4/ } \\
\text { Germany }\end{array}$ & $\begin{array}{l}2008 \ldots \\
199119952 / \\
2008 \ldots\end{array}$ & $21 \%$ & $\begin{array}{l}\text { Mauritania } \\
\text { Mexico } \\
\text { Mexico }\end{array}$ & $\begin{array}{l}19841984 \\
198119852 / \\
19941996\end{array}$ & $\begin{array}{l}8 \% \\
27 \% \\
14 \%\end{array}$ & $\begin{array}{l}\text { Tanzania } \\
\text { Thailand } \\
\text { Thailand }\end{array}$ & $\begin{array}{l}1987 \\
1983 \\
1997\end{array}$ & $\begin{array}{l}1988 \\
1983 \\
2000\end{array}$ & $\begin{array}{c}0 \% \\
25 \% \\
109 \%\end{array}$ \\
\hline $\begin{array}{l}\text { Burkina Faso } \\
\text { Burundi } \\
\text { Cameroon } \\
\text { Cameroon } \\
\text { Cape Verde }\end{array}$ & $\begin{array}{l}19901994 \\
199419982 / \\
198719912 / \\
19951997 \\
19931993\end{array}$ & $\begin{array}{c}121 \% \\
106 \% \\
8 \% \\
0 \%\end{array}$ & $\begin{array}{l}\text { Ghana } \\
\text { Greece 3/ } \\
\text { Guinea } \\
\text { Guinea } \\
\text { Guinea-Bissau }\end{array}$ & $\begin{array}{l}19821983 \\
2008 \ldots \\
198519851 / \\
19931993 \\
19951998\end{array}$ & $\begin{array}{c}45 \% \\
29 \% \\
0 \% \\
0 \% \\
30 \%\end{array}$ & $\begin{array}{l}\text { Mongolia } \\
\text { Morocco } \\
\text { Mozambique } \\
\text { Nepal } \\
\text { Netherlands }\end{array}$ & $\begin{array}{l}2008 \ldots \\
198019842 / \\
198719912 / \\
19881988 \\
2008 \ldots\end{array}$ & $\begin{array}{c}0 \% \\
22 \% \\
0 \% \\
0 \% \\
25 \%\end{array}$ & \begin{tabular}{|l} 
Togo \\
Tunisia \\
Turkev \\
Turkev \\
Uganda
\end{tabular} & $\begin{array}{l}1993 \\
1991 \\
1982 \\
2000 \\
1994\end{array}$ & $\begin{array}{l}1994 \\
1991 \\
1984 \\
2001 \\
1994\end{array}$ & \begin{tabular}{c|}
$39 \%$ \\
$1 \%$ \\
$35 \%$ \\
$37 \%$ \\
$0 \%$
\end{tabular} \\
\hline Central African Rep & 19761976 & $0 \%$ & Guyana & 19931993 & $0 \%$ & Nicaragua & 19901993 & $11 \%$ & Ukraine 4/ & 1998 & 1999 & $0 \%$ \\
\hline Central African Rep & 19951996 & $9 \%$ & Haiti & 19941998 & $38 \%$ & Nicaragua & 20002001 & $0 \%$ & Ukraine & 2008 & $\ldots$ & $5 \%$ \\
\hline $\begin{array}{l}\text { Chad } \\
\text { Chad }\end{array}$ & $\begin{array}{l}19831983 \\
199219962 /\end{array}$ & $\begin{array}{l}0 \% \\
0 \%\end{array}$ & $\begin{array}{l}\text { Hungarv 4/ } \\
\text { Hungary 3/ }\end{array}$ & $\begin{array}{l}199119952 / \\
2008 \ldots\end{array}$ & $\begin{array}{c}0 \% \\
42 \%\end{array}$ & $\begin{array}{l}\text { Niger } \\
\text { Nigeria }\end{array}$ & $\begin{array}{l}19831985 \\
199119952 /\end{array}$ & $\begin{array}{c}97 \% \\
0 \%\end{array}$ & $\begin{array}{l}\text { United Kingdom } \\
\text { United States 3/ }\end{array}$ & $\begin{array}{l}2007 \\
1988\end{array}$ & $\ldots$ & $\begin{array}{c}24 \% \\
0 \%\end{array}$ \\
\hline $\begin{array}{l}\text { Chile } \\
\text { Chile } \\
\text { China, Mainland }\end{array}$ & $\begin{array}{l}19761976 \\
198119852 / \\
19981998\end{array}$ & $\begin{array}{c}20 \% \\
9 \% \\
19 \%\end{array}$ & $\begin{array}{l}\text { Iceland } \\
\text { India } \\
\text { Indonesia }\end{array}$ & $\begin{array}{l}2008 \ldots \\
19931993 \\
199720012 /\end{array}$ & $\begin{array}{c}42 \% \\
0 \% \\
69 \%\end{array}$ & $\begin{array}{l}\text { Norway } \\
\text { Panama } \\
\text { Paraguay }\end{array}$ & $\begin{array}{l}19911993 \\
19881989 \\
19951995\end{array}$ & $\begin{array}{c}5 \% \\
85 \% \\
15 \%\end{array}$ & $\begin{array}{l}\text { United States } \\
\text { Uruguav } \\
\text { Uruguay }\end{array}$ & $\begin{array}{l}2007 \\
1981 \\
2002\end{array}$ & $\begin{array}{l}\ldots \\
19852 / \\
2005\end{array}$ & $\begin{array}{l}25 \% \\
38 \% \\
27 \%\end{array}$ \\
\hline $\begin{array}{l}\text { Colombia } \\
\text { Colombia } \\
\text { Congo, Dem Rep }\end{array}$ & $\begin{array}{l}19821982 \\
19982000 \\
19831983\end{array}$ & $\begin{array}{c}47 \% \\
43 \% \\
1 \%\end{array}$ & $\begin{array}{l}\text { Ireland } \\
\text { Israel } \\
\text { Jamaica }\end{array}$ & $\begin{array}{l}2008 \ldots \\
19771977 \\
19961998\end{array}$ & $\begin{array}{l}110 \% \\
76 \% \\
38 \%\end{array}$ & \begin{tabular}{|l} 
Peru \\
Philippines \\
Philippines 3/
\end{tabular} & $\begin{array}{l}198319831 / \\
19831986 \\
199720012 /\end{array}$ & $\begin{array}{c}55 \% \\
92 \% \\
0 \%\end{array}$ & $\begin{array}{l}\text { Venezuela } \\
\text { Vietnam } \\
\text { Yemen }\end{array}$ & $\begin{array}{l}1994 \\
1997 \\
1996\end{array}$ & $\begin{array}{l}19982 / \\
1997 \\
1996\end{array}$ & $\begin{array}{c}1 \% \\
0 \% \\
16 \%\end{array}$ \\
\hline Congo, Dem Rep & $199119942 /$ & $130 \%$ & Japan & $199720012 /$ & $45 \%$ & Poland 4/ & 19921994 & $0 \%$ & Zambia & 1995 & 1998 & $31 \%$ \\
\hline Congo, Dem Rep & $199419982 /$ & $79 \%$ & Jordan & 19891991 & $106 \%$ & Portugal 3/ & $2008 \ldots$ & $37 \%$ & Zimbabwe & 1995 & $19992 /$ & $10 \%$ \\
\hline
\end{tabular}

$1 /$ Credit data missing. For these countries, end dates are based on GDP growth only.

2/ We truncate the duration of crises at 5 years, starting with the first crisis year.

$3 /$ Borderline cases.

4/ No output losses are reported for crises in transition economies that took place during the period of transition to market economies.

Output losses computed as the cumulative difference between actual and trend real GDP, expressed as a percentage of trend real GDP for the period [T, T+3] where T is the starting year of the crisis. Trend real GDP is computed by applying an HP filter $(\lambda=100)$ to the GDP series over [T-20, T-1].

Source: World Economic Outlook (WEO), Laeven and Valencia (2008), and authors' calculation. 


\section{Policy Responses IN THE 2007-2009 CRISES: What Is NeW?}

Crisis management starts with the containment of liquidity pressures through liquidity support, guarantees on bank liabilities, deposit freezes, or bank holidays. This containment phase is followed by a resolution phase during which typically a broad range of measures (such as capital injections, asset purchases, and guarantees) are taken to restructure banks and reignite economic growth. It is intrinsically difficult to compare the success of crisis resolution policies given differences across countries and time in the size of the initial shock to the financial system, the size of the financial system, the quality of institutions, and the intensity and scope of policy interventions. With this caveat we now compare policy responses during the recent crisis episode with those of the past.

The policy responses during the 2007-2009 crises episodes were broadly similar to those used in the past. First, liquidity pressures were contained through liquidity support and guarantees on bank liabilities. Like the crises of the past, during which bank holidays and deposit freezes have rarely been used as containment policies, we have no records of the use of bank holidays during the recent wave of crises, while a deposit freeze was used only in the case of Latvia for deposits in Parex Bank. On the resolution side, a wide array of instruments was used this time, including asset purchases, asset guarantees, and equity injections. All these measures have been used in the past, but this time around they seem to have been put in place quicker (for detailed information about the frequency of policy interventions in past crisis episodes, see Laeven and Valencia, 2008).

One commonality among the recent crises is that they mostly affected advanced economies with large, internationally integrated financial institutions that were deemed too large and/or interconnected to fail. The large international networks and cross-border exposures of these financial institutions helped propagate the crisis to other countries. Failure of any of these large financial institutions could have resulted in the failure of other systemically important institutions, either directly by imposing large losses through counterparty exposures or indirectly by causing a panic that could generate bank runs. This prompted large-scale government interventions in the financial sector (including preemptive measures in some countries).

Given that the crisis started in U.S. subprime mortgage markets, financial exposure to the United States was as key propagation mechanism of the crisis (see Claessens et al., 2010). Figure 1 shows foreign claims by nationality of reporting banks, from the BIS consolidated banking statistics, expressed as percent of GDP, as of end-2006. Cross border banking exposure to the US varied a great deal across countries, ranging from less than 1 percent for Mexico to 300 percent for Switzerland. Eight out of ten of the most exposed economies meet our systemic banking crisis definition or are categorized as borderline cases. 


\section{Figure 1. Foreign Claims by Nationality of Reporting Banks}

As percentage of GDP at end of year 2006

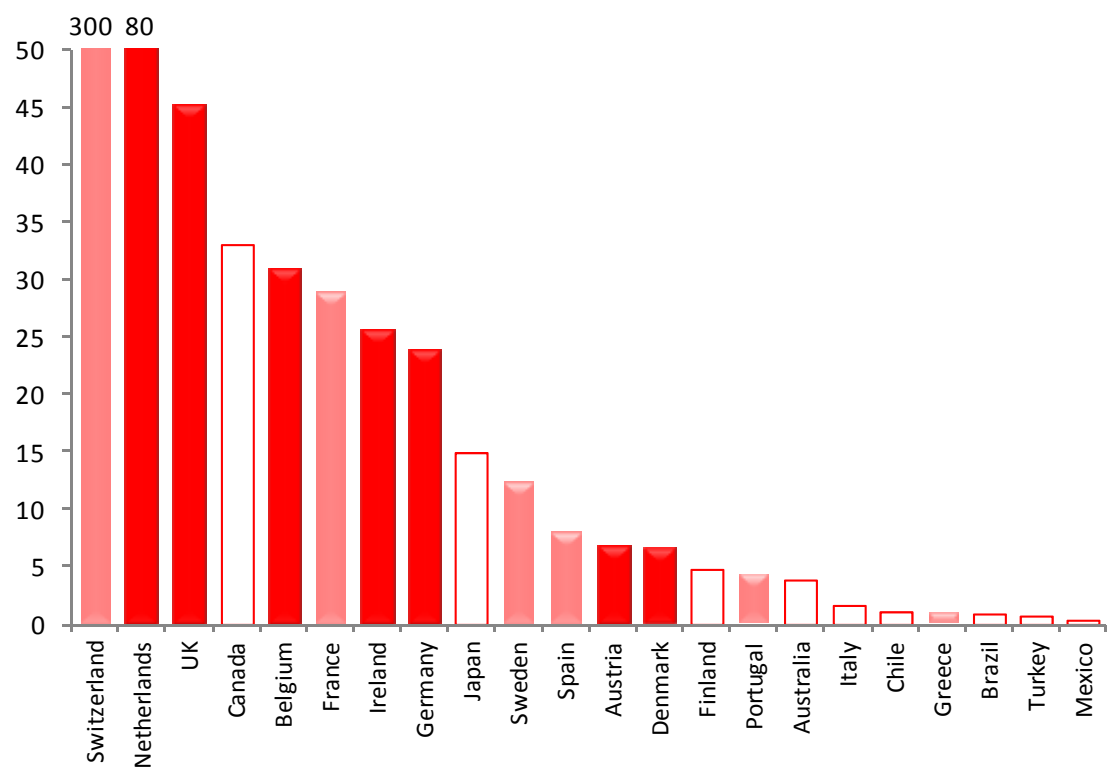

Note: Dark solid bars denote systemic banking crises and light solid bars denote borderline cases. Figures denote foreign claims by nationality on the United States at end-2006 as percentage of home country GDP. Source: BIS

Liquidity support was used intensively as a first line of response to this shock emanating from the United States. Not only was liquidity provision large, as illustrated in Figure 2, but it was also made available more broadly through a larger set of instruments and institutions (including nonbank institutions), and under weaker collateral requirements. Examples of unconventional liquidity measures include the Federal Reserve's decision to grant primary broker-dealers access to the discount window, the widening of collateral accepted by the Federal Reserve and many other central banks, and the purchase of asset-backed securities by the Federal Reserve. These actions were also accompanied in some cases by the introduction of nonconventional facilities to fund non-financial companies directly, such as the Federal Reserve's Commercial Paper Facility and the Bank of England's Asset Purchase Facility.

This significant liquidity provision is reflected in a large increase in central bank claims against the financial sector. The median change from the pre-crisis level to its peak in the ratio of central bank claims against the financial sector to deposits and foreign liabilities amounts to 5.5 percent. ${ }^{11}$ This is about half its median in past crisis episodes. For comparison

\footnotetext{
${ }^{11}$ For Germany and Luxembourg, while at the peak this variable reached 9.4 and 14.7 percent respectively, the increments look small because banks in these countries already maintained high balances prior to the crisis due to cross-border settlements. Liquidity support is computed as the ratio of Central Bank Claims on deposit money banks (line 12 in IFS) to total deposits and liabilities to non-residents. Total deposits are computed as the sum of demand deposits (line 24), other deposits (line 25), and liabilities to non-residents (line 26).
} 
purposes, Figure 2 also reports the historical median of liquidity support among high-income countries only, since most recent crises occurred in high-income economies (all crisis countries except Mongolia, Latvia, and Ukraine). ${ }^{12}$

\section{Figure 2. Emergency Central Bank Liquidity Support}

Over the period 2007 to 2009

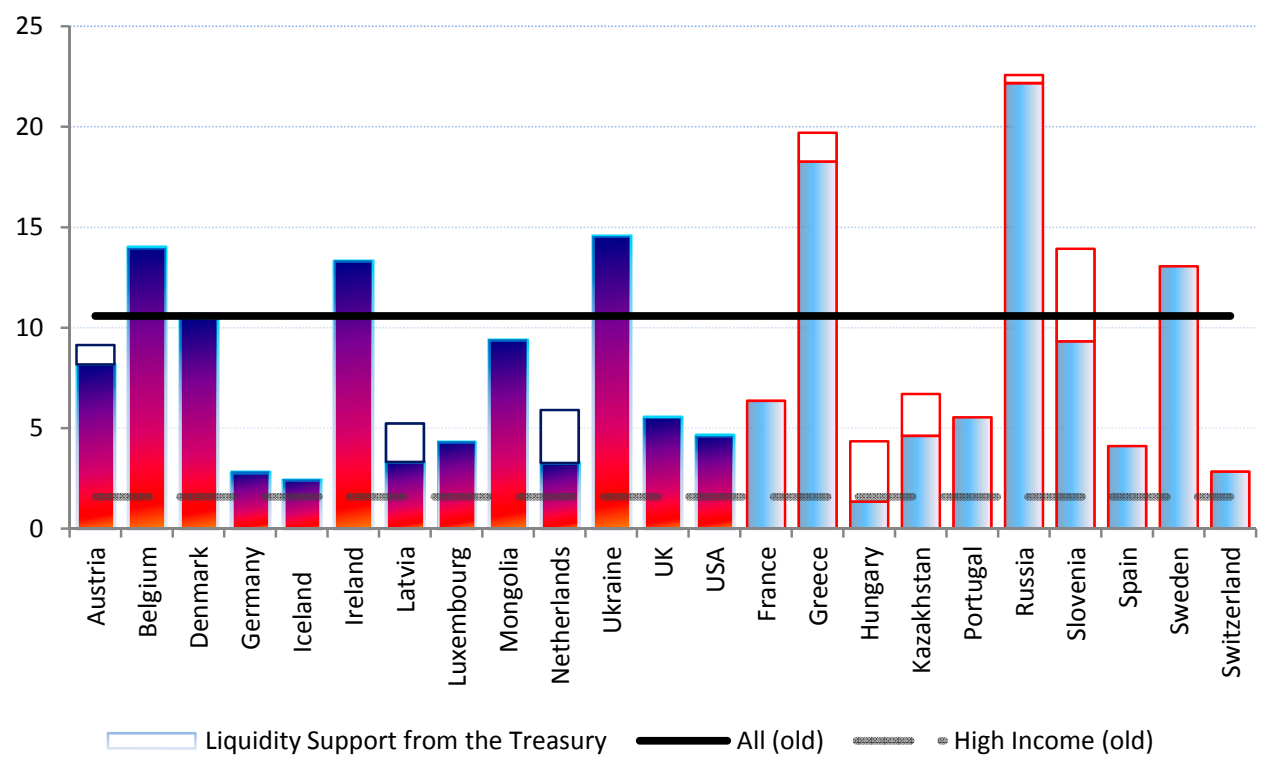

Note: The shaded figures represent the change in the ratio of central bank claims on the financial sector over total deposits and foreign liabilities between the peak of this ratio and the average for the year before the crisis. The non-shaded figures represent the total amount of liquidity support funded directly by the Treasury (between 2007 and 2009) over total deposits and foreign liabilities. Dark-shaded bars denote systemic crisis cases, while light-shaded bars denote non-systemic crises. For Iceland, liquidity data was available only up to March 2008. Horizontal lines denote the medians classified by countries' income level for historical data. All (old): all previous countries; High income (old): high-income previous episodes.

Source: Laeven and Valencia (2008), IFS, and authors' calculations.

In some cases, liquidity was also provided directly by the treasury, as indicated in Figure 2. Slovenia shows the largest increase in liquidity funded by the treasury, amounting to close to 5 percent of deposits and foreign liabilities. Similarly, government deposits at Parex Bank in Latvia constituted an important source of liquidity assistance for this bank. ${ }^{13}$ Liquidity injected in countries labeled as borderline has also been significant, in particular for Greece, Russia, and Sweden. For Greece, liquidity support increased steadily starting in September

\footnotetext{
${ }^{12}$ It is worth clarifying that there are only 5 historical (pre-2007) crisis episodes among high-income countries in our historical sample.

${ }^{13}$ In the case of Latvia, the threshold used in our definition of extensive liquidity support is satisfied once government deposits at Parex are counted as liquidity support.
} 
2009. In Russia, liquidity support subsided quickly after reaching a peak of 20 percent of deposits and foreign liabilities in 2009.

Guarantees on bank liabilities have also been widely used during recent crisis episodes to restore confidence of bank liability holders. All crisis countries except Ukraine (and Kazakhstan, Sweden, and Switzerland among borderline cases) extended guarantees on bank liabilities other than raising deposit insurance limits. Coverage extended varied widely, though (Appendix Table A.1). While guarantees on bank liabilities have not been uncommon in past crises, asset guarantees have been used less frequently in the past. This time around, asset guarantees were used in some cases, including Belgium and the United Kingdom. For instance, the Bad Bank Act in Germany, passed in July 2009, provided private banks relieve on holdings of illiquid assets by allowing them to transfer assets to a special entity and receive government-guaranteed bonds issued by this special entity in exchange. While direct fiscal costs for Germany amount to just above 1 percent of GDP, total guarantees (including those associated with the Bad Bank and financial institutions debt) reached about 6 percent. ${ }^{14}$

One measure of the length of a crisis is the time it takes central banks to withdraw liquidity support. As a measure of the time it took the withdraw liquidity support, we compute the number of months between the peak of liquidity support and the month when liquidity support declined to its pre-crisis level. In earlier crises, emergency liquidity support was withdrawn within 14 months (median). However, this time around, as of end-2009 only Denmark, Germany, Hungary, Luxembourg, the Netherlands, and Switzerland saw their liquidity support returned to pre-crisis levels, suggesting that liquidity remained an issue for a prolonged time in recent crises.

We also consider the overall size of monetary expansion, by computing the change in the monetary base, and find that monetary expansion is significantly higher in recent crises compared to past crises. Figure 3 shows the change in the monetary base between its peak during the crisis and its level one year before the crisis, expressed in percentage points of GDP. ${ }^{15}$ We find that the median monetary expansion of about 6 percent this time significantly exceeded its historical median of about 1 percent, though it is not that different from its historical median among high-income countries. Relatively larger financial systems and credibility of monetary policy in high income economies may explain this difference.

\footnotetext{
${ }^{14}$ Because Germany's Bad Bank implies asset transfers, it could also be treated as asset purchases. Yet, we treat it as guarantees, and therefore do not list Germany as also having met the significant asset purchases threshold.

${ }^{15}$ Data on reserve money comes from IFS. For Euro-area countries, reserve money corresponds to the aggregation of currency issued and liabilities to depository corporations, divided by Euro area GDP.
} 
Figure 3. Monetary Expansion

Over the period 2007 to 2009

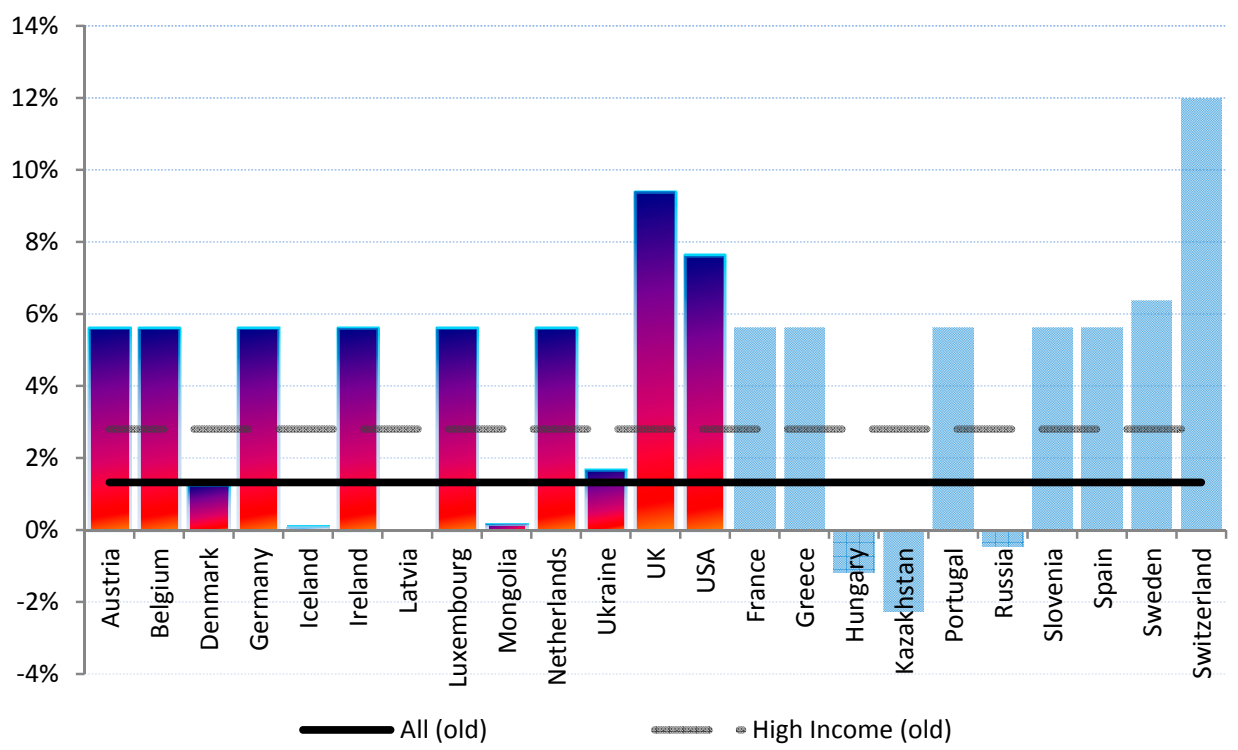

Note: Change in monetary base in percentage points of GDP between the peak and its level one year before the crisis. Horizontal lines denote the medians by country groups. All (old): all countries; High income (old): highincome countries.

Source: IFS, Laeven and Valencia (2008) and authors' calculations.

About 70 percent of fiscal outlays correspond to public sector recapitalizations of financial institutions. Bank recapitalizations, while not more common than in earlier crisis episodes, have been implemented much faster than in the past. The median difference between the time it took to implement public recapitalization programs and the time that liquidity support became extensive (that is, when liquidity support exceeded 5 percent) is zero months for the recent crises compared to 12 months for past crises (Figure 4). ${ }^{16}$ Addressing solvency problems with public money is generally a complex and lengthy process because it requires political consensus and legislation. Policymakers therefore often prolong the use of liquidity support and guarantees in the hope that problems in the banking sector subside. This time around, though, policymakers acted with relative speed, at least in some countries. ${ }^{17}$

\footnotetext{
${ }^{16}$ For bank recapitalizations, we only consider "comprehensive" recapitalization packages in which public funds were used, thereby excluding ad hoc interventions and biasing upwards our estimate of the response time. In the new crises, three recapitalization programs targeted specific banks: Iceland (the three largest banks), Luxembourg (Fortis and Dexia), and Latvia (Parex). We include the last two in our calculation because of the size of the affected institutions. However, the median does not change if we exclude them. We do not include Iceland because of limited data on liquidity support as to compute the date when it became extensive.

${ }^{17}$ In many cases, banks were able to raise capital in private markets or from parent banks, and generally this took place before public money was used. In addition, many banks have temporarily been allowed to avoid the recognition of market losses and thereby overstate regulatory capital.
} 


\section{Figure 4. Timing of Recapitalization Policies}

Over the period 2007 to 2009

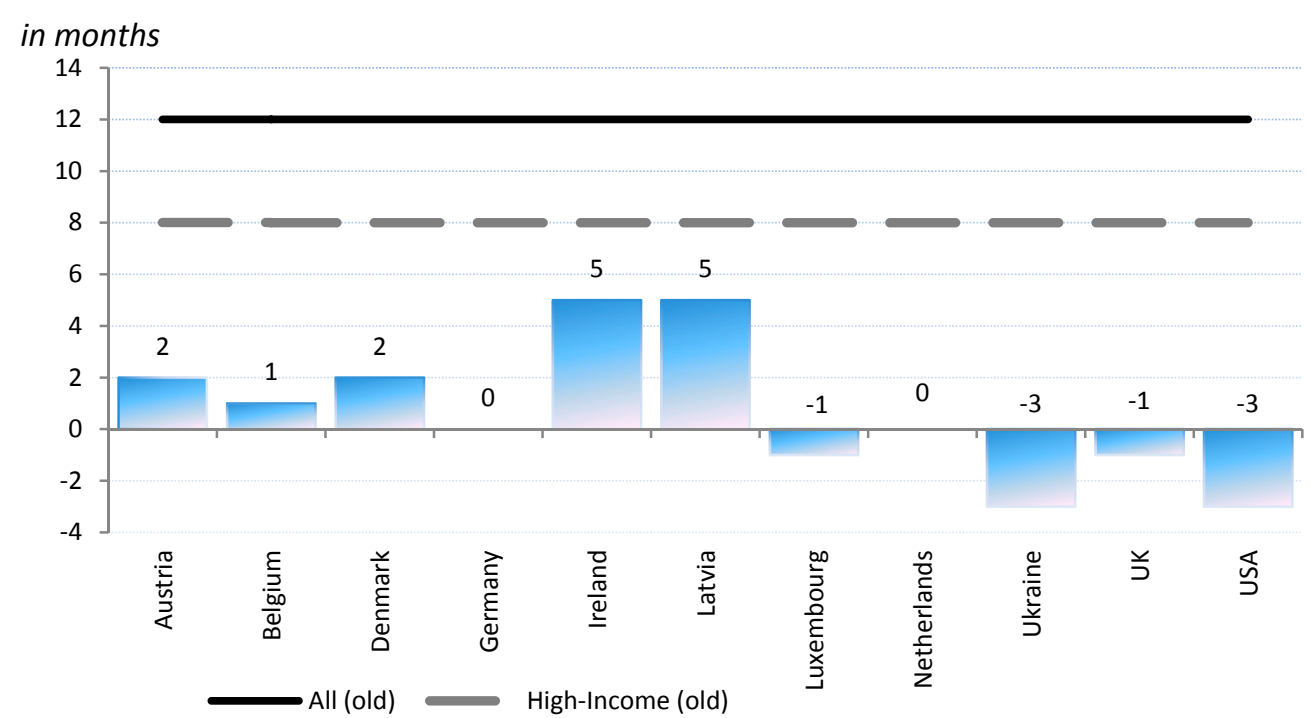

Note: Time in months between moment when liquidity support became extensive and implementation of recapitalization plans. Horizontal line denotes the median across all and high-income past crises in which recapitalization plans were put in place.

Source: Laeven and Valencia (2008) and authors' calculations.

Governments typically acquire stakes in the banking sector as part of government recapitalization programs, and such ownership stakes often end up being held by the government for a prolonged period of time. Although divestments (or repayments) of government support on average start about one year from the start of the crisis, suggesting that the early repayments from the TARP capital support program witnessed in the US are not uncommon, government participation in banks has in many cases largely exceeded the initially envisioned holding period. ${ }^{18}$ In many cases, the public sector retained participation for over 10 years (in Japan, for instance, as of end-2008 over 30 percent of capital injected in financial institutions following the crisis in 1997 remained to be sold). In some cases, divestment took place by tender, through sales of entire institutions to foreign investors or large domestic banks; in other cases, it took place more gradually through markets.

Bank failures - defined broadly by including institutions that received government assistance - have also been significant during the recent wave of crises. This is striking given that bank failures are rare events in most countries, in part due to regulatory forbearance and too-big-to fail or close problems. Relative to the total assets in the banking system, the bank failures in Iceland are by far the most significant, at about 90 percent of total banking assets (Figure 5). Iceland is followed by Greece and Belgium with banks that failed or received

\footnotetext{
${ }^{18}$ A comprehensive analysis of guidelines for exit strategies from crises can be found in Blanchard et al. (2010).
} 
government assistance representing 80 percent or more of banking system assets in each of these three countries. When using the more conservative definition of failure that excludes government assistance, Iceland is followed by Belgium, Kazakhstan, and the United Kingdom, with banks representing 53 percent, 28 percent, and 26 percent, respectively, of the system failing. In terms of banks receiving government assistance, Greece tops the charts, with banks holding 80 percent of total banking system assets receiving some form of government assistance. Greece is followed by France and Ireland, with banks holding about 70 and 55 percent, respectively, of banking system assets receiving government assistance.

Figure 5. Bank Failures and Interventions in Selected Countries

Failures and interventions as a \% of total banking assets over the period August 2007 to August 2009

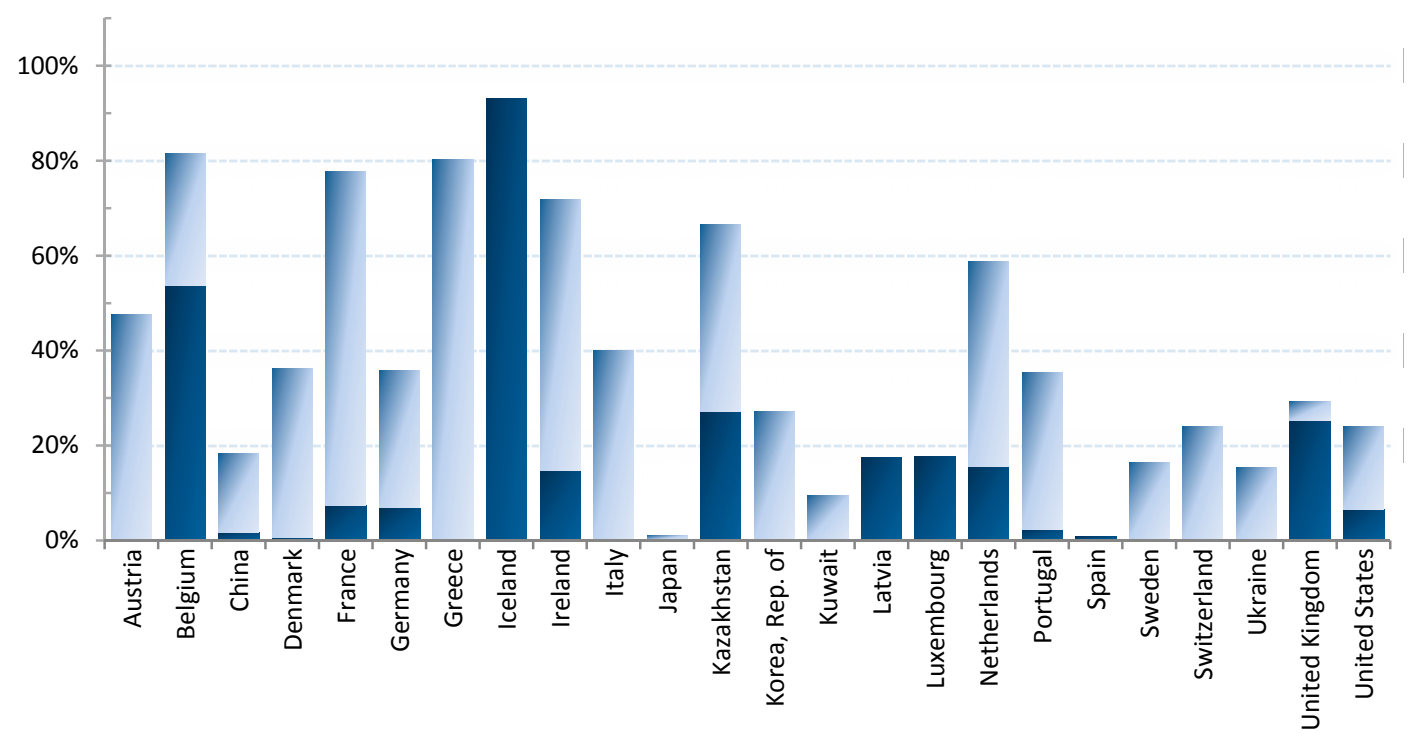

— Failed banks, fraction of total banking assets (\%) Government-assisted banks, fraction of total banking assets (\%)

Note: Government-assistance implies public capital support resulting in the government holding a minority stake in the bank. Failure implies bank closure; bank taken over by government; nationalization; or public capital support resulting in the government becoming a majority shareholder.

Source: Authors' calculations based on data from IMF, EU, FDIC, and JIDC.

At least for the US, for which historical data on bank failures since the 1930s is available, the recent wave of failures including assistance is unprecedented, with banks holding about onequarter of the deposit market having failed or received some of form of government assistance since 2007 (see Box 1 for a more detailed analysis of historical U.S. bank failures). Excluding banks that received public assistance, the year 1989 during the U.S. savings and loan crisis is by far the worst year on record, with banks holding over $6 \%$ of the deposit market failing. The United States is clearly not an outlier this time around, even when using the broader definition of bank failures that includes government assistance. Of course, the U.S. failure list excludes such large financial institutions as Fannie, Freddie Mac, and AIG because they are not banks, although they meet our definition of failure, and we could therefore underestimate the magnitude of financial distress in the United States. 


\section{Box 1. U.S. Bank Failures: Past and Present}

U.S. bank failures since the 1930s have come in three waves: the Great Depression era of the 1930s, the savings and loans crisis of the 1980s, and the recent mortgage crisis of the late 2000s, with the number of bank failures peaking in the years 1937, 1989, and 2009, respectively. Compared to these earlier bank failure episodes, the current wave of bank failures appears more short-lived and, at least compared to the savings and loans crisis, less dramatic in terms of number of failing banks (Figure 6). Note that 2005 and 2006 were the only two years since 1934 that reported no bank failures.

Figure 6. U.S. Bank Failures: Fraction of Failed Banks Over the period 1934 to 2010

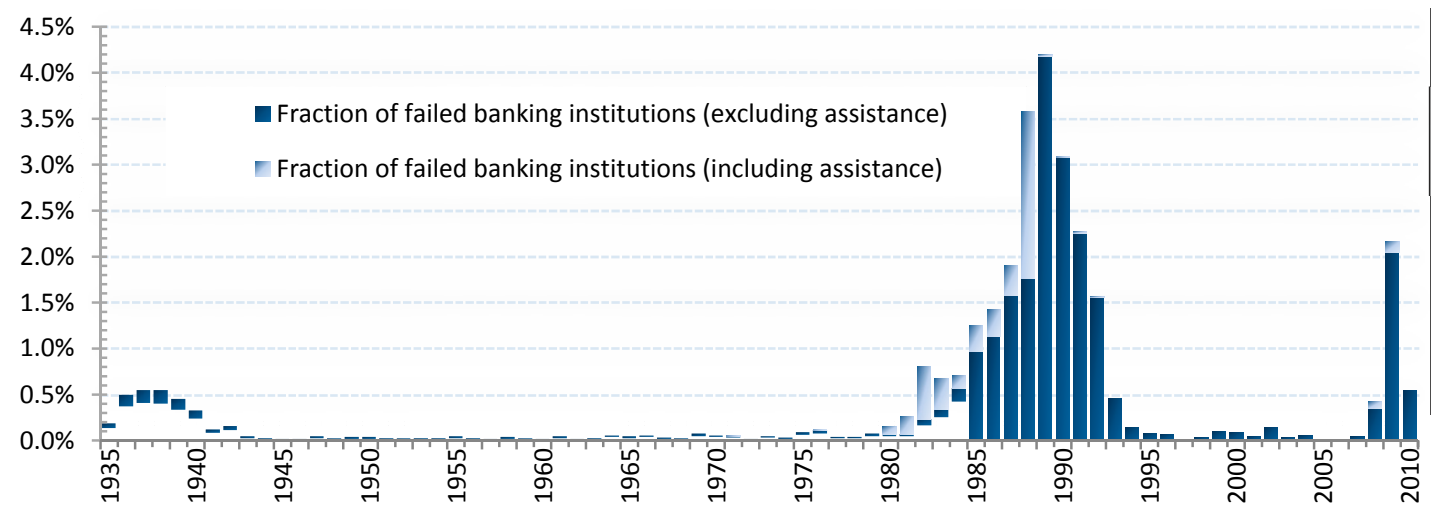

Note: The figures include all failures and assistance transactions across 50 U.S. states and Washington DC, as percent of total number of institutions. 2010 includes data up to April. Source: FDIC.

Owing in part to consolidation following financial deregulation starting in the 1980s, the average U.S. bank has grown substantially in size. After accounting for this development, the recent failures look a lot worse. Failed U.S. banks during the current crisis hold about 26 percent of the deposit marketthat is, when including banks that did not fail but received government assistance, such as Citigroup and Bank of America (Figure 7). Using this definition of failure, 2009 is by far the worst on record. When excluding banks that received public assistance, the year 1989 is the worst year on record.

Figure 7. U.S. Bank Failures: Market Share of Failed Banks Over the period 1934 to 2010

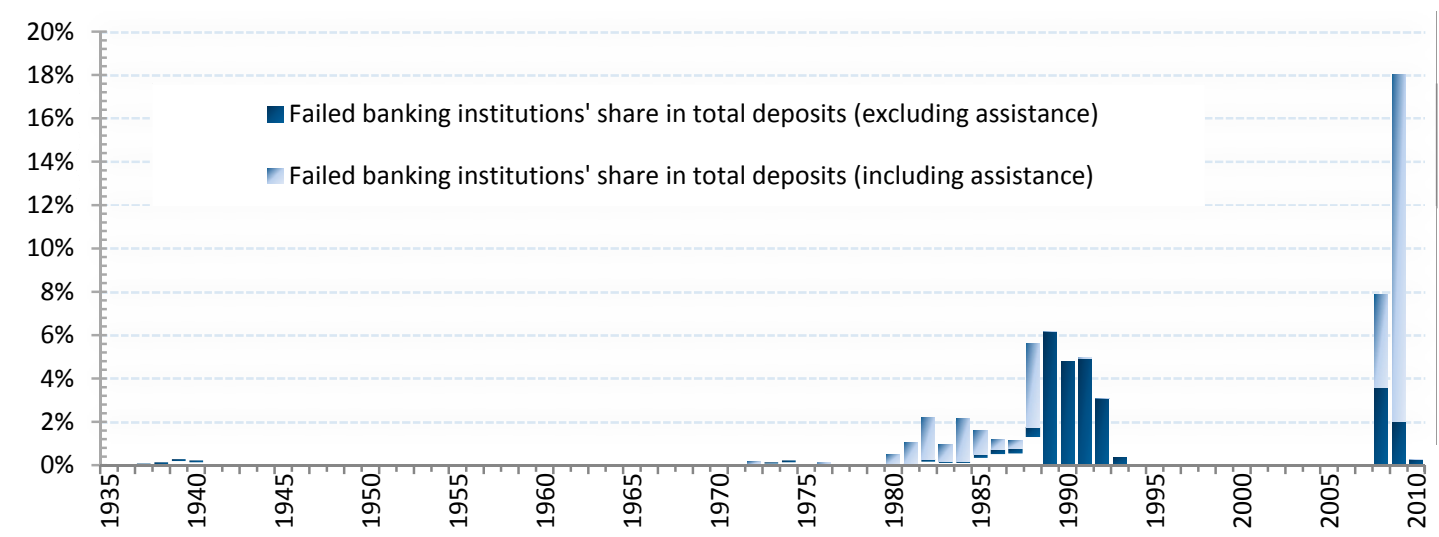

Note: The figures include the fraction of system deposits held by all bank failures and assistance transactions across 50 U.S. states and Washington DC, as percentage of total deposits. Source: FDIC. 
Recent bank failures have generated similar losses compared to the past, with a median loss rate to the deposit insurance fund on assets of failed banking institutions of 19 percent (Figure 8). Median losses are relatively stable over the examined period (data on loss rates are available starting in 1986), and roughly the same during the recent crisis as compared to the savings and loan crisis. The median loss rate peaked in 2008 at 28 percent. In terms of losses to the deposit insurer, we do not have data for the year 2009 yet, but losses were significantly lower in 2008, at 0.12 percent of U.S. GDP, than the highest loss on record in 1989 of 0.97 percent of U.S. GDP. Overall, we find that, in the particular case of the United States, the failure rate of banks and losses incurred by the government in closing failed banks in this crisis is similar compared to the U.S. banking crisis of the 1980's with a median loss rate in bank failures of about 20 percent of bank assets.

\section{Figure 8. U.S. Bank Failures: Loss Rates on Assets of Failed Banks}

Over the period 1986 to 2008

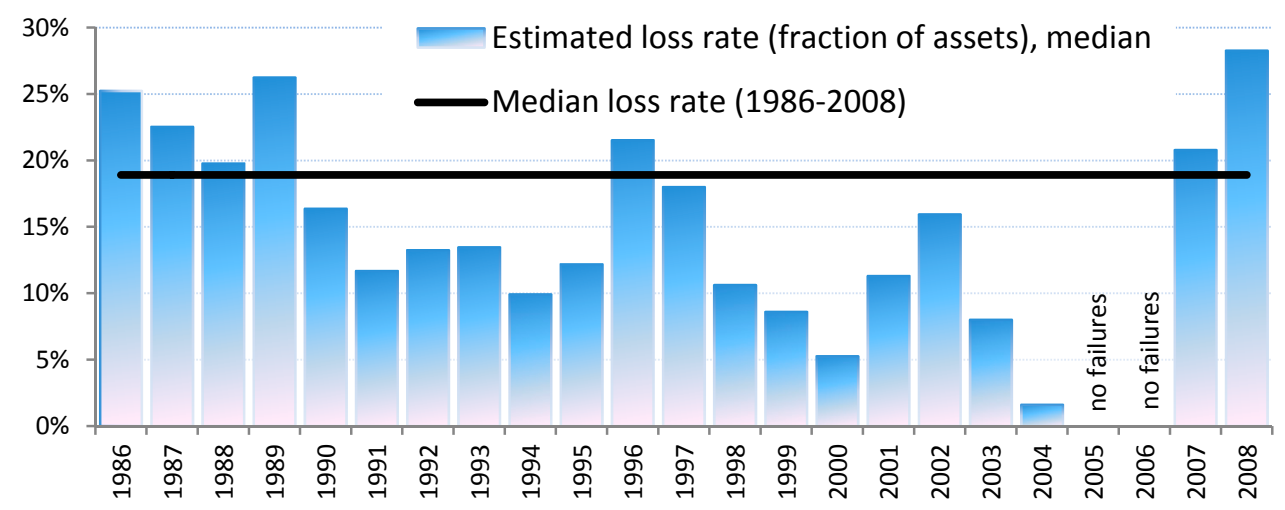

Note: Includes all failures and assistance transactions across 50 U.S. states and Washington DC. Loss rates are expressed as a percentage of total bank assets. Total assets are for FDIC-insured commercial banks only. We report median loss rates by year. The estimated loss is the difference between the amount disbursed from the Deposit Insurance Fund (DIF) to cover obligations to insured depositors and the amount estimated to be ultimately recovered from the liquidation of the receivership estate. Estimated losses reflect unpaid principal amounts deemed unrecoverable and do not reflect interest that may be due on the DIF's administrative or subrogated claims should its principal be repaid in full. Source: FDIC.

A consequence of these dramatic bank failures has been a re-organization of the worlds' financial map, with large players becoming significantly smaller, freeing up space for new players, in particular emerging markets. Bank failures during the recent wave of crises have been particularly dramatic for the U.S. and some of the countries in Western Europe that before the crisis were top tier players in global banking. Before the crisis, at end-2006, the top 30 banks worldwide had a total stock market capitalization of about US\$ 3.4 trillion dollars, of which 40 percent belonged to U.S. banks, 12 percent to U.K. banks, and 12 percent to Japanese banks (see Table 3). ${ }^{19}$ Countries with a systemic banking crisis in 20072009 dominated the banking arena in 2006 with a share of close to 60 percent of the total.

\footnotetext{
${ }^{19}$ A complete list of global top-30 banks in 2006 and 2009 is reported in Appendix Table A.4.
} 
The crisis changed the map significantly. Twelve banks dropped from the top-30 list of 2006, with 3 banks being acquired by other institutions. The overall loss in market capitalization of the top-30 banks between 2006 and 2009 was a staggering 52 percent, a figure that already includes a significant stock market recovery during 2009. The largest decline in market capitalization corresponds to Citigroup — excluding banks that were acquired by other institutions - however, at the country-level, the Netherlands (including Fortis) experienced the largest average decline, followed by Japan. The latter is surprising given that Japan is not even classified as a borderline systemic banking crisis (because, although announced policy interventions in Japan were significant, the actual usage of these resources was small).

Table 3. Market Capitalization of Top 30 Banks Worldwide, by Nationality As of end of year 2006 and 2009

\begin{tabular}{|c|c|c|c|c|}
\hline & \multicolumn{2}{|c|}{ \# of banks } & \multicolumn{2}{|c|}{$\%$ of market capitalization } \\
\hline & End-2006 & End-2009 & End-2006 & End-2009 \\
\hline US & 10 & 5 & 39.8 & 20.9 \\
\hline UK & 4 & 3 & 12.5 & 13.9 \\
\hline France & 3 & 3 & 7.8 & 8.8 \\
\hline Japan & 3 & 1 & 11.9 & 2.5 \\
\hline Netherlands and Belgium 1/ & 3 & 0 & 6.9 & 0.0 \\
\hline Spain & 2 & 2 & 6.5 & 9.5 \\
\hline Switzerland & 2 & 2 & 7.5 & 4.9 \\
\hline Canada & 1 & 2 & 1.8 & 5.0 \\
\hline Italy & 1 & 2 & 2.9 & 5.1 \\
\hline Germany & 1 & 1 & 2.4 & 2.1 \\
\hline Australia & 0 & 4 & 0.0 & 8.8 \\
\hline Brazil & 0 & 2 & 0.0 & 4.4 \\
\hline China & 0 & 2 & 0.0 & 12.2 \\
\hline Sweden & 0 & 1 & 0.0 & 1.9 \\
\hline Total & 30 & 30 & 100.0 & 100.0 \\
\hline
\end{tabular}

1/ Includes two Dutch institutions and Fortis, a Dutch-Belgian financial conglomerate.

Source: Bankscope. Banks used in the calculation are listed in Appendix Table A.4.

How does the list of the world's top-30 banks look like now? Interestingly, as of end-2009 there are four countries that for the first time entered this list. These include Australia, Brazil, China, and Sweden. On the other hand, Netherlands and Belgium-listed together because of jointly-owned Fortis - drop from the top-30 ranking in 2009. The United States has fallen to only 5 banks in this list, together holding only 21 percent of the market capitalization of the world's 30 largest banks in 2009 compared to 40 percent in 2006. The United States is clearly the country for which the change in market capitalization share is the most dramatic. Other clear losers include the Netherlands and Japan. While in 2006 no emerging market appeared on the list, at end-2009 banks from Brazil and China together were holding 16 percent of the total market capitalization of top-30 banks worldwide. Other clear winners are Australia and Canada whose large banks mostly escaped the US mortgage crisis. 


\section{How Costly Are the 2007-2009 Systemic Banking Crises?}

We estimate the cost of each crisis using three metrics: direct fiscal costs, output losses, and the increase in public sector debt relative to GDP. Direct fiscal costs include fiscal outlays committed to the financial sector from the start of the crisis up to end-2009 (see Appendix Table A.3 for a list of items included), and capture the direct fiscal implications of intervention in the financial sector. ${ }^{20}$ Output losses are computed as deviations of actual GDP from its trend, and the increase in public debt is measured as the change in the public debt-toGDP ratio over the four-year period beginning with the crisis year. ${ }^{21}$ Output losses and the increase in public debt capture the overall real and fiscal implications of the crisis.

Table 4. Summary of the Cost of Banking Crises

Over the period 1970-2009

\begin{tabular}{lccc}
\hline & Direct Fiscal Cost & Increase in Public Debt & Output Losses \\
\hline \hline & & Medians (\% of GDP) \\
\hline Old crises (1970-2006) & 3.7 & 36.2 & \\
Advanced economies & 11.5 & 12.7 & 32.9 \\
Emerging markets & 10.0 & 16.3 & 29.4 \\
All & & & 19.5 \\
\hline New crises (2007-2009) & 5.9 & 25.1 & 24.8 \\
Advanced economies & 4.8 & 23.9 & 4.7 \\
Other economies & 4.9 & 23.9 & 24.5 \\
All & & & \\
\hline \hline
\end{tabular}

Note: New crises include Austria, Belgium, Denmark, Germany, Iceland, Ireland, Latvia, Luxembourg, Mongolia, Netherlands, Ukraine, United Kingdom, and United States.

Source: Laeven and Valencia (2008) and authors' calculations.

The recent crises are overall more costly in terms of output losses and increases in debt, but less so in terms of direct fiscal outlays compared to the average crisis of the past. However, when we limit the comparison to high-income countries - given they dominate the new crises

\footnotetext{
${ }^{20}$ It is too early to provide reliable estimates about future recoveries and losses for recent crises, but wherever funds have been recovered, they have been included in Table A.3. Also, we do not include potential losses arising from contingent liabilities (such as asset guarantees) and schemes funded by the central bank (such as asset purchases), although we recognize that losses in those schemes may ultimately have fiscal consequences.

${ }^{21}$ Output losses are computed as the cumulative sum of the differences between actual and trend real GDP over the period [T, T+3], expressed as a percentage of trend real GDP, with $T$ the starting year of the crisis. Trend real GDP is computing by applying an HP filter (with $\lambda=100$ ) to the log of real GDP series over [T-20, T-1] (or shorter if data is not available, though we require at least 4 pre-crisis observations). Real GDP is extrapolated using the trend growth rate over the same period. Real GDP data are from WEO. For recent crisis episodes, GDP projections are based on April 2010 WEO. We truncate the duration of a crisis at 5 years, including the first year. Wherever our methodology results in a crisis duration over 5 years, or when data availability impede us from applying our methodology, we set the end year as the fifth year from the crisis start year.
} 
sample - we find that output losses are similar compared to the past, increases in public debt somewhat lower, but direct fiscal outlays higher (Table 4).

The median direct fiscal costs associated with financial sector restructuring for the 20072009 systemic banking crises amounts to almost 5 percent of GDP, about half its historical median of 10 percent. ${ }^{22}$ Figure 9 plots the direct fiscal costs for the recent systemic crises, as well as for the borderline cases. Two horizontal lines indicate the median of fiscal costs in all previous crises and that among previous high-income crisis episodes. Greece, Kazakhstan, Russia, and Slovenia show the highest figures among the borderline cases, although for Slovenia all of it corresponds to liquidity support from the treasury in the form of bank deposits. For Greece and Kazakhstan, at least half of it is also liquidity assistance from the treasury, while only for Russia the entire amount corresponds to recapitalization. As one would expect, on average, direct fiscal costs for borderline cases are lower than those for the systemic crises. Iceland shows up with the highest fiscal outlays, at 13 percent of GDP. ${ }^{23}$

Figure 9. Direct Fiscal Costs

In percent of GDP and over the period 2007-2009

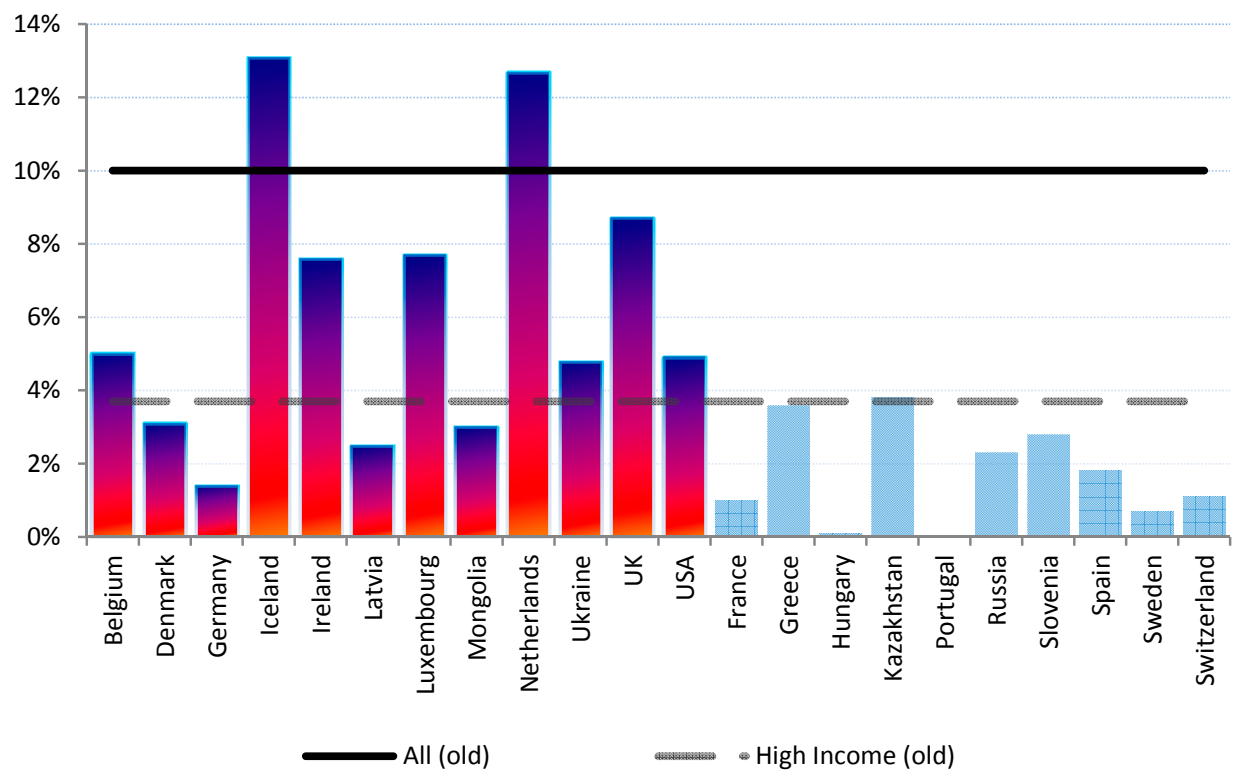

Note: Dark-shaded bars denote systemic banking crises episodes, and light-shaded bars borderline cases. The horizontal lines represent the medians across crises prior to 2007. Income groups are based on the World Bank country classification. All (old): all old episodes; High income (old): all old crises in high-income countries. Source: Laeven and Valencia (2008) and Authors' calculations

\footnotetext{
${ }^{22}$ These higher fiscal costs in part reflect an increase in average banking system size.

${ }^{23}$ These costs exclude the obligations (mostly to the United Kingdom and the Netherlands) arising from the Icesave crisis, which in net present value terms IMF staff estimates to be around 16 percent of GDP.
} 
We regard the lower direct fiscal outlays associated with high income countries, relative to all past crises, a consequence of the greater flexibility these countries have in supporting their financial system indirectly through expansionary monetary and fiscal policy and direct purchases of assets that help sustain asset prices. Additionally, some high income countries opted for sizable contingent liabilities to complement direct fiscal outlays (see Table A.3).

Given that countries can also indirectly support their financial sector at times of crisis through expansionary fiscal policies that support output and employment, it is useful to also consider the overall increase in public debt as a broader estimate of the fiscal cost of the crisis. The median debt increase among recent crises is 24 percent of GDP, about 8 percentage points higher than its historical median of 16 percent. Thus, public debt burdens have increased significantly as a consequence of policy measures taken during the crisis.

Figure 10. Increase in Public Debt In percent of GDP and over the period 2007-2011 (estimated)

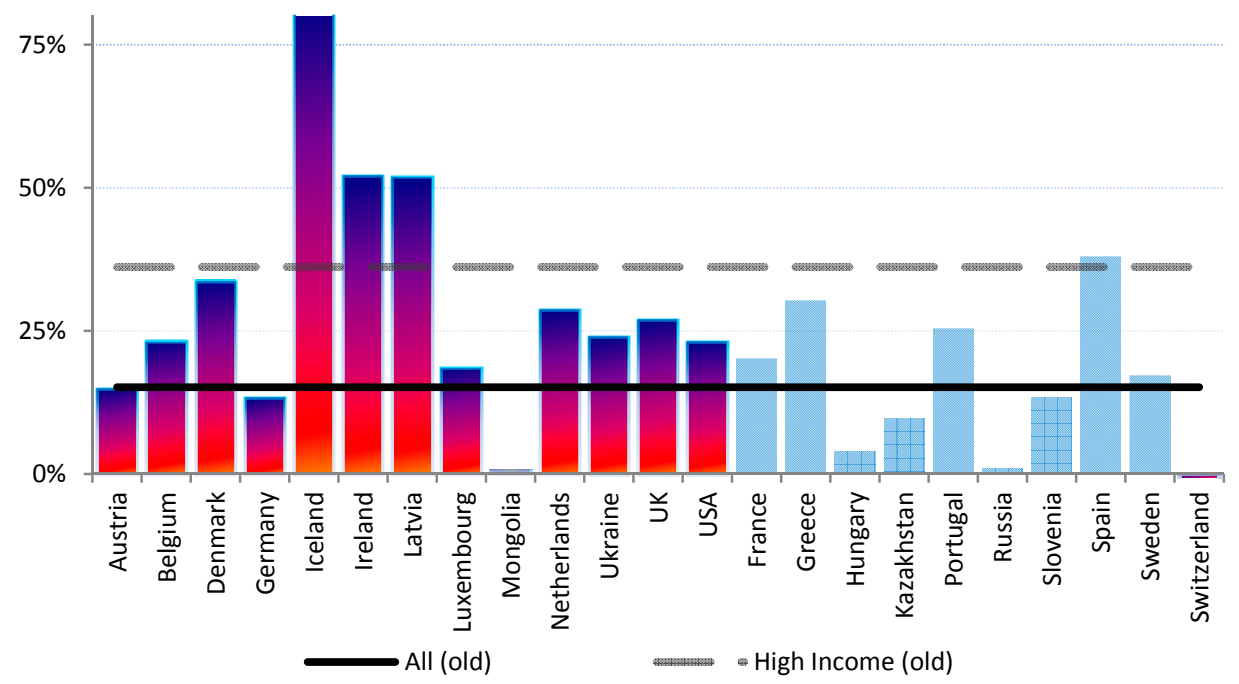

Note: Dark-shaded bars denote systemic banking crises episodes, and light-shaded bars denote borderline cases. Increase in public debt is the increase in gross general government debt (central government debt if not available) over GDP, estimated over the 3 year period following the start of the crisis using WEO debt forecasts. Horizontal lines denote medians across past crises, classified by income level. All (old): all past crises in emerging and high-income countries; High income (old): all past crises in high-income countries. Source: Laeven and Valencia (2008), WEO and authors' calculations.

Figure 10 shows the increase in the public debt burden for each crisis and also reports the historical median of the increase in public debt at crisis times. We approximate the increase in public debt that can be attributed to the crisis by computing the difference between preand post-crisis debt projections. For the 2007-2009 crises, we use the fall WEO debt projections from the year before the crisis year as pre-crisis debt figures (i.e., September 2006 WEO for the UK and US and October 2007 WEO for all other recent crises) and the 
Spring WEO 2010 debt projections for the post-crisis debt figures. For past episodes, we simply report the actual change in debt. ${ }^{24}$

Among the recent borderline cases, France, Greece, Portugal and Spain exhibit the largest expected increases in debt. While overall fiscal stimulus packages to counteract the global recession were significant in some of these countries, the direct interventions in the financial sector were not sufficient - as of end-2009 - to qualify as systemic banking crises. Recent developments in Greece, since our cutoff date at end-2009, while significant, are still not sufficient for it to qualify as a systemic banking crisis, at least as of April 2010.

\section{Figure 11. Increase in Public Debt and Direct Fiscal Costs} In percent of $G D P$

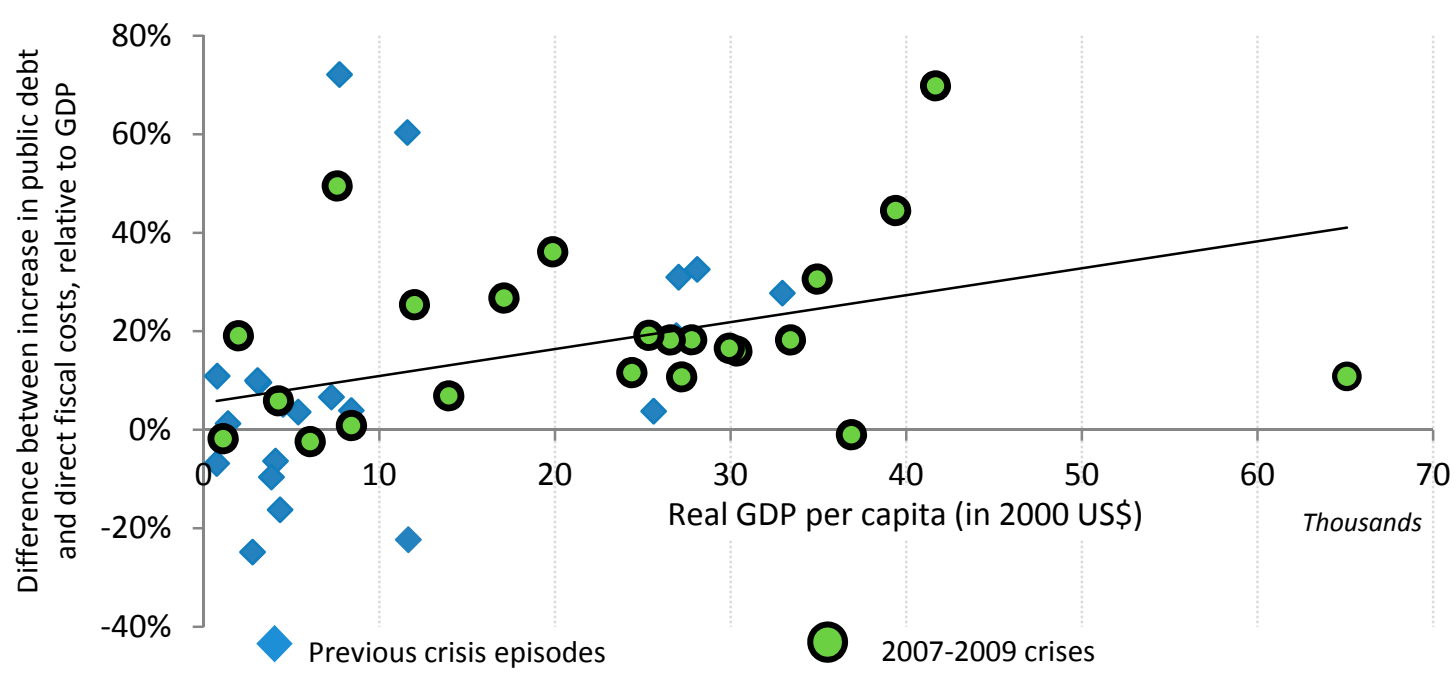

Note: Circles denote the new systemic and borderline episodes, while diamonds denote old episodes. The y-axis corresponds to the difference between the increase in public debt and gross fiscal costs, both in percent of GDP. The x-axis corresponds to real GDP per capita, measured in 2000 US\$. Old episodes exclude countries that experienced a sovereign debt crisis using data from Laeven and Valencia (2008).

Source: Laeven and Valencia (2008), WEO, and authors' calculations.

The previous two graphs suggest a large difference between increases in fiscal costs arising from direct support to the financial sector and increases in overall public debt. This difference appears to be positively correlated at about 0.4 with an economy's level of income (Figure 11). Given that direct fiscal outlays to support the financial sector generally increase public debt, the difference between the increase in public debt and fiscal costs reflect in part the outcome of measures taken to support the real sector. This difference can in part be

\footnotetext{
${ }^{24}$ We compute the increase in debt measured in percent of GDP over [T-1, T+3], where $\mathrm{T}$ is the starting year of the crisis. Our choice of sources is guided by the availability of general government debt. When it is not available, central government debt is reported instead. Our primary data source is WEO. When WEO debt data are not available, we resort to the OECD Analytical Database and the IMF's Government Finance Statistics.
} 
explained by discretionary fiscal policy and automatic stabilizers. One possible interpretation of this positive correlation is that high-income economies generally face easier financing opportunities than their low-income counterparts, and therefore may choose to complement financial measures with expansionary fiscal measures to deal with banking crises. Clearly, expansionary fiscal policy indirectly supports the financial sector by stimulating aggregate demand, which in turn props up loan demand and lowers the risk of loan defaults.

The fallout from the recent crisis on the real sector was large. We estimate median output losses for the recent crises of 25 percent of GDP, which is almost 5 percentage points higher than its historical median of 20 percent. Output losses are estimated by computing the difference between trend GDP and actual GDP over the four-year period beginning with the crisis year. Therefore, our methodology does not distinguish between permanent and transitory output losses. For the new crises, we use spring 2010 WEO projections as actual GDP for the post-crisis years. Figure 12 shows the results. ${ }^{25}$

Figure 12. Output Losses

In percent of potential output

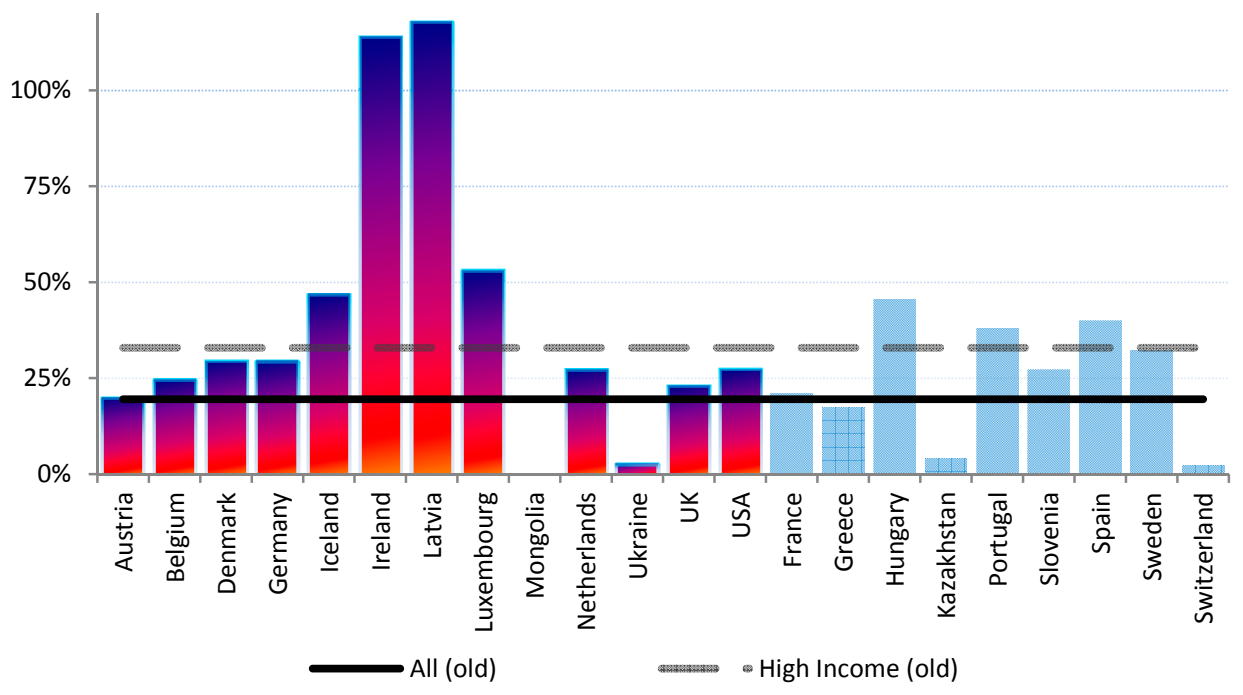

Note: Dark-shaded bars denote systemic banking crises episodes, and light-shaded bars denote borderline cases. Output losses are computed as cumulative percent difference between actual and trend real GDP over the 4-year period starting with the crisis year. Trend GDP is computed applying an HP filter to the real GDP series over the 20-year period prior to the crisis. Horizontal lines denote the historical medians classified by countries' income level. All (old): all past crises; High income (old): all past crises in high-income countries. Source: Laeven and Valencia (2008), WEO, and authors' calculations.

\footnotetext{
${ }^{25}$ The medians reported in the graph are based on output losses that have been recomputed for all crisis episodes using the methodology employed in this paper rather than by relying on estimates of output losses in Laeven and Valencia (2008). They computed the real GDP trend using all available data, implying a different horizon for each country. The new output loss estimates are on average similar to those in Laeven and Valencia (2008), though they differ for low-income countries and countries affected by large shocks, such as wars.
} 
Output losses differ depending on the size of the initial shock, differences across countries in how the shock was propagated through the financial system, and the intensity of policy interventions. The output losses for Ireland and Latvia stand out at over 100 percent of potential GDP. Losses among borderline cases are also significant, in particular for Hungary, Portugal, and Spain. On average, countries with larger financial systems, and especially those that experienced rapid expansion prior to the crisis (such as Iceland, Ireland, and Latvia), were hit hardest.

\section{Concluding Remarks}

This paper updates the Laeven and Valencia (2008) database on systemic banking crises through end-2009 to include the recent wave of financial crises following the U.S. mortgage crisis of 2007. Our update results in 13 new systemic banking crises episodes and 10 borderline cases since early 2007. The update makes several improvements to the earlier database, including an improved definition of systemic banking crisis, the inclusion of crisis ending dates, and a broader coverage of crisis management policies.

The new data shows that there are many commonalities between recent and past crises, both in terms of underlying causes and policy responses. All crises share a containment phase during which liquidity pressures are contained through liquidity support and in some cases guarantees on bank liabilities. This phase is followed by a resolution phase during which a broad range of measures is taken to restructure banks and encourage bank lending (including asset purchases, guarantees, and capital injections) to reignite economic growth. These common patterns echo earlier findings summarized in Honohan and Laeven (2005) and Reinhart and Rogoff (2009).

However, the recent wave of crises also shows some important differences with previous crisis episodes.

- First, the recent crisis was concentrated in advanced economies, in particular those with large and integrated financial systems, unlike many of the boom-bust cycles observed in the past that centered on emerging market economies. Liquidity shortages at systemically important, globally interconnected financial institutions in these advanced economies prompted large-scale government interventions.

- Second, while the intensity of policy interventions has been comparable to past crisis episodes, the speed of intervention and implementation of resolution policies was faster this time. This in part reflects that most of the crisis-affected countries are highincome countries with strong legal, political, and economic institutions that create an enabling environment for an effective and speedy crisis resolution. Recapitalization policies in particular were implemented much sooner than in the past, contributing to lower direct fiscal outlays. 
- Third, countries used a much broader range of policy measures compared to past episodes, including unconventional monetary policy measures, asset purchases and guarantees, and significant fiscal stimulus packages. These large scale public interventions were possible in part because most of the crisis-affected countries are high-income countries with relatively greater institutional quality and credibility of policy actions.

- Fourth, preliminary estimates indicate that the overall economic costs of the recent crises are higher in terms of output losses and increases in public debt compared to past crises, though fiscal costs associated with financial sector interventions are lower this time.

The lower short-run fiscal costs in part reflect the relatively swift action with which governments announced recapitalization measures and took other actions to restore the health of the financial system. However, they are also a consequence of the significant indirect support the financial system received through expansionary monetary and fiscal policy, the widespread use of guarantees on liabilities, and direct purchases of assets that helped sustain asset prices. The significant support deployed through monetary and fiscal policies, including coordinated international efforts to ensure adequate foreign exchange liquidity, and a timely implementation of measures to address solvency problems in the financial system have significantly contributed to reduce the real impact of the recent crises. Moreover, such indirect support from macroeconomic stabilization policies has also lifted the burden on traditional crisis management policies, ultimately keeping the direct fiscal costs associated with bank recapitalization and other direct interventions into the financial sector lower than they otherwise would have been.

However, over the medium term, these indirect support measures have significantly increased the burden of public debt and the size of government contingent liabilities, raising concerns about fiscal sustainability in a number of countries. Moreover, the crisis is still ongoing in several countries and its ultimate impact will have to be reassessed in the future. It may therefore be premature to hail recent crisis management efforts as being more successful than those of the past. 


\section{References}

Acharya, Viral, and Matthew Richardson, 2009, Restoring Financial Stability: How to Repair a Failed System, John Wiley and Sons Inc., Hoboken, New Jersey.

Adrian, Tobias, and Hyun Shin, 2008, "Financial Intermediaries, Financial Stability, and Monetary Policy," Federal Reserve Bank of New York Staff Report 346.

Blanchard, Olivier J., Carlo Cottarelli, and José Viñals, 2010, “Exiting from Crisis Intervention Policies," IMF Policy Paper SM/10/10, Washington, DC.

Brunnermeier, Markus, 2009, "Deciphering the Liquidity and Credit Crunch 2007-2008," Journal of Economic Perspectives, Vol. 23, pp. 77-100.

Caprio, Gerard, Daniela Klingebiel, Luc Laeven, and Guillermo Noguera, 2005, "Banking Crisis Database," in Patrick Honohan and Luc Laeven (eds.), Systemic Financial Crises: Containment and Resolution. Cambridge, U.K.: Cambridge University Press.

Cheasty, Adrienne, and Udaibir Das, 2009, "Crisis-Related Measures in the Financial System and Sovereign Balance Sheet Risks,” IMF Policy Paper SM/09/91, Washington, DC.

Claessens, Stijn, Giovanni Dell'Ariccia, Deniz Igan, and Luc Laeven, 2010, "Cross-Country Experiences and Policy Implications from the Global Financial Crisis," Economic Policy, Vol. 62, pp. 267-93.

Dell'Ariccia, Giovanni, Luc Laeven, and Deniz Igan, 2008, "Credit Booms and Lending Standards: Evidence from the Subprime Mortgage Market," IMF Working Paper 08/106, Washington, DC.

Gorton, Gary, 2008, “The Panic of 2007,” NBER Working Paper No. 14358.

Honohan, Patrick, and Luc Laeven (eds.), 2005, Systemic Financial Crises: Containment and Resolution. Cambridge, U.K.: Cambridge University Press.

Keys, Benjamin, Tanmoy Mukherjee, Amit Seru, and Vikrant Vig, 2010. "Did Securitization Lead to Lax Screening? Evidence From Subprime Loans," Quarterly Journal of Economics, Vol. 125, pp. 307-62.

Laeven, Luc, and Fabian Valencia, 2008, "Systemic Banking Crises: A New Database," IMF Working Paper No. 08/224, Washington, DC.

Mian, Atif, and Amir Sufi, 2009, "House Prices, Home Equity-Based Borrowing, and the U.S. Household Leverage Crisis," American Economic Review, forthcoming.

Obstfeld, Maurice, and Kenneth Rogoff, 2009, "Global Imbalances and the Financial Crisis: Products of Common Causes," Unpublished manuscript.

Taylor, John, 2009, Getting Off Track: How Government Actions and Interventions Caused, Prolonged, and Worsened the Financial Crisis, Hoover Press.

Reinhart, Carmen, and Kenneth Rogoff, 2009, This Time is Different: Eight Centuries of Financial Folly, Princeton University Press. 
Table A.1. Systemic Banking Crises Policy Responses

During the years 2007 to 2009

\begin{tabular}{|c|c|c|c|c|c|}
\hline Country & $\begin{array}{l}\text { Liquidity Support } \\
\text { (percentage points increase in } \\
\text { central bank claims on } \\
\text { financial institutions over } \\
\text { deposits and foreign liabilities) }\end{array}$ & $\begin{array}{l}\text { Gross Restructuring Costs } \\
\text { (recapitalization and other } \\
\text { restructuring costs, excluding } \\
\text { liquidity and asset purchases, } \\
\text { in percent of GDP) }\end{array}$ & $\begin{array}{l}\text { Asset Purchases and } \\
\text { Guarantees } \\
\text { (funded by treasury } \\
\text { and central bank, in } \\
\text { percent of GDP) }\end{array}$ & $\begin{array}{l}\text { Guarantees on Liabilities } \\
\text { (significant guarantees on bank liabilities in } \\
\text { addition to increasing deposit insurance ceilings) }\end{array}$ & $\begin{array}{l}\text { Nationalizations } \\
\text { (state takes control over } \\
\text { institutions; year of } \\
\text { nationalization between } \\
\text { brackets) }\end{array}$ \\
\hline Austria & 8.2 & 2.1 & Guarantees: 0.6 & $\begin{array}{l}\text { Unlimited coverage to depositors. } \\
\text { Bank and non-bank bond issues. }\end{array}$ & $\begin{array}{l}\text { Hypo Group Alpe Adria } \\
\text { (2009) }\end{array}$ \\
\hline Belgium & 14.0 & 5.0 & Guarantees: 7.7 & $\begin{array}{l}\text { DI raised from } € 20,000 \text { to } € 100,000 \text {. } \\
\text { Deposit-like insurance instruments. } \\
\text { Interbank loans and short-term debt } \\
\text { Specific guarantees on Dexia }\end{array}$ & Fortis (2008) \\
\hline Denmark & 10.5 & 2.8 & & Deposits and unsecured claims of PCA banks & Fionia Bank (2009) \\
\hline Germany & 2.8 & 1.2 & Purchases: 0.2 & $\begin{array}{l}\text { Unlimited coverage of household deposits. } \\
\text { Interbank loans and bank debt (capped at } € 400 \\
\text { billion). }\end{array}$ & Hypo Real Estate (2008) \\
\hline Iceland & 2.4 & 13.0 & & Unlimited coverage to domestic deposits. & $\begin{array}{l}\text { Kaupthing, Landsbanki, Glitnir, } \\
\text { Straumur-Burdaras, SPRON and } \\
\text { Sparisjódabankinn (all 2008) }\end{array}$ \\
\hline Ireland & 13.3 & 7.6 & & $\begin{array}{l}\text { Unlimited coverage until 9/29/10 to most liabilities } \\
\text { of } 10 \text { banks. }\end{array}$ & Anglo Irish Bank (2009) \\
\hline Latvia & 3.3 & 2.5 & & $\begin{array}{l}\text { DI raised to } € 50,000 \text {. } \\
\text { Guarantee on Parex syndicated loans }\end{array}$ & Parex Bank (2008) \\
\hline Luxembourg & 4.3 & 7.7 & & $\begin{array}{l}\text { DI raised from } € 20,000 \text { to } € 100,000 \text {. } \\
€ 4.5 \text { billion guarantee on Dexia's debt. }\end{array}$ & $\begin{array}{l}\text { Fortis and Dexia's subsidiaries } \\
(2008)\end{array}$ \\
\hline Mongolia & 9.4 & 3.0 & & Unlimited coverage to all deposits. & Zoos Bank (2009) \\
\hline Netherlands & 3.3 & 6.5 & Guarantees: 3.3 & $\begin{array}{l}\text { DI raised to } € 100,000 \text {. } \\
\text { Interbank loans of solvent banks. } \\
\text { Fortis bonds ( } € 5 \text { bn) and ING bonds ( } € 10 \mathrm{bn}) \text {. }\end{array}$ & ABN-AMRO/Fortis (2008) \\
\hline Ukraine & 14.6 & 4.8 & & $\begin{array}{l}\text { DI raised from UAH } 50,000 \text { to } 150,000 \text { until } \\
1 / 1 / 11 \text {. }\end{array}$ & $\begin{array}{l}\text { Prominvest (2008), Nadra, } \\
\text { Inprom, Volodimrski, Dialog, } \\
\text { Rodovid, Kiev, Ukrgaz (all } \\
\text { 2009) }\end{array}$ \\
\hline
\end{tabular}


DI raised from $£ 35,000$ to 50,000 .

$\begin{array}{llll}\text { United Kingdom } & 5.5 & 5.1 & \text { Purchases: } 13.4 \\ & & \text { Guarantees: } 14.5\end{array}$

Guarantee on short- to medium-term debt (capped

at £250 billion).

Northern Rock (2008); RBS

Blanket guarantee on Northern Rock and

(2008).

Bradford \& Bingley wholesale deposits.

DI raised from $\$ 100,000$ to $\$ 250,000$ (until end-

2009).

Money market funds (capped at 50 billion)

Full guarantee on transaction deposits.

Fannie Mae, Freddie Mac, AIG

Newly issued senior unsecured debt.

\section{Borderline Cases}

\begin{tabular}{|c|c|c|c|c|c|}
\hline France & 6.4 & & & $\begin{array}{l}\text { DI already higher than EU new limit. } \\
€ 360 \text { billion in guarantees for refinancing credit } \\
\text { institutions. } \\
€ 55 \text { billions Dexia's debt }\end{array}$ & \\
\hline Greece & 18.3 & 1.7 & & $\begin{array}{l}\text { DI raised from } € 20,000 \text { to } € 100,000 \text {. } \\
\text { Funding guarantees up to } € 15 \text { billion. }\end{array}$ & \\
\hline Hungary & 1.3 & 0.1 & & Unlimited protection to depositors of small banks. & \\
\hline Kazakhstan & 4.6 & 2.4 & & DI raised from T0.7 million to T5 million. & \\
\hline Portugal & 5.5 & & & $\begin{array}{l}\text { DI raised from } € 25,000 \text { to } € 100,000 \text {. } \\
\text { Debt securities issued by credit institutions (up to } \\
12 \text { percent of GDP) }\end{array}$ & $\begin{array}{l}\text { Banco Portugues de Negócios } \\
\text { (small bank) (2008) }\end{array}$ \\
\hline Russia & 22.2 & 1.0 & & $\begin{array}{l}\text { DI raised from R400,000 to R700,000. } \\
\text { Interbank lending for qualifying banks. }\end{array}$ & \\
\hline Slovenia & 9.3 & & & $\begin{array}{l}\text { Unlimited protection for all deposits by } \\
\text { individuals and small enterprises until end-2010. } \\
\text { New debt issued by financial institutions until } \\
\text { end-2010. }\end{array}$ & \\
\hline Spain & 4.1 & & & $\begin{array}{l}\text { DI raised from } € 20,000 \text { to } € 100,000 \text {. } \\
\text { Credit Institutions New Debt Issues (capped at } \\
€ 200 \text { billion). }\end{array}$ & \\
\hline Sweden & 13.1 & 0.7 & & $\begin{array}{l}\text { DI raised from SEK } 250,000 \text { to SEK 500,000. } \\
\text { Medium-term debt of banks and mortgage } \\
\text { institutions (up to SEK } 1.5 \text { trillion). }\end{array}$ & \\
\hline Switzerland & 2.8 & 1.1 & Purchases: 6.7 & $\begin{array}{l}\text { DI raised from SFr } 30,000 \text { to } S F r ~ 100,000 \text { until } \\
12 / 31 / 11 \text {. }\end{array}$ & \\
\hline
\end{tabular}

Source: IMF Staff Reports, Mayer Brown, Official websites, and IFS 
Table A.2. Preemptive Crisis Responses in Selected G-20 Countries

During the years 2007 to 2009

\begin{tabular}{|c|c|c|c|c|c|}
\hline Country & $\begin{array}{l}\text { Liquidity Support } \\
\text { (Percentage points increase in } \\
\text { central bank claims on } \\
\text { financial institutions over } \\
\text { deposits and foreign liabilities, } \\
\text { relative to pre-crisis level) }\end{array}$ & $\begin{array}{l}\text { Gross Restructuring Costs } \\
\text { (recapitalization and other } \\
\text { restructuring costs, excluding } \\
\text { liquidity and asset purchases, } \\
\text { in percent of GDP) }\end{array}$ & $\begin{array}{l}\text { Asset Purchases and } \\
\text { Guarantees } \\
\text { (Funded by treasury } \\
\text { and central bank, in } \\
\text { percent of GDP) }\end{array}$ & $\begin{array}{l}\text { Guarantees on Liabilities } \\
\text { (significant: in addition to increasing deposit } \\
\text { insurance (DI) ceilings, guarantees of other } \\
\text { liabilities) }\end{array}$ & $\begin{array}{l}\text { Nationalizations } \\
\text { (State takes control over } \\
\text { institutions; year of } \\
\text { nationalization between } \\
\text { brackets) }\end{array}$ \\
\hline Australia & $\mathrm{n} / \mathrm{a}$ & & & $\begin{array}{l}\text { Unlimited coverage to deposits (if above } 1 \\
\text { million, only those with maturity }<5 \text { years). }\end{array}$ & \\
\hline Canada & 1.8 & & Purchases: 4.4 & $\begin{array}{l}\text { Temporary insurance on the wholesale term } \\
\text { borrowing of deposit-taking institutions. } \\
\text { Increased deposit insurance in some } \\
\text { provinces. }\end{array}$ & \\
\hline Italy & 2.5 & 0.8 & & & \\
\hline Japan & 1.1 & $<0.1$ & $\begin{array}{l}\text { Purchases: } 1.1 \\
\text { Guarantees: } 2.6 \\
\text { (SME's) }\end{array}$ & & \\
\hline Korea & 2.1 & 0.8 & $\begin{array}{l}\text { Purchases: }<0.1 \\
\text { Guarantees: } 1.8 \\
\text { (SME's) }\end{array}$ & $\begin{array}{l}\text { Payment guarantees to Korean banks' } \\
\text { external debt ( } \$ 100 \text { billion cap). }\end{array}$ & \\
\hline
\end{tabular}

Source: IMF Staff Reports, Mayer Brown, Official websites, and IFS. 
Table A.3. Direct Fiscal Outlays, Recoveries to Date, and Asset Guarantees

During the years 2007 to 2009

\begin{tabular}{|c|c|c|c|c|}
\hline & & Gross & Recoveries ${ }^{1 /}$ & Net \\
\hline \multicolumn{5}{|l|}{$\overline{\text { Austria }}$} \\
\hline Recapitalizations & Capital Injection Program & 2.1 & & \\
\hline \multirow[t]{2}{*}{ Asset Purchases } & impaired assets and liquidity & 2.0 & & \\
\hline & Total Fiscal Outlays & 4.1 & & 4.1 \\
\hline Asset Guarantees & Asset guarantee program & 0.6 & & \\
\hline \multicolumn{5}{|l|}{ Belgium } \\
\hline Recapitalization & Ethias, Fortis, KBC, and Dexia & 4.7 & & \\
\hline \multirow[t]{2}{*}{ Other } & Capital for Fortis SPV & 0.2 & & \\
\hline & Total Fiscal Outlays & 5.0 & & 5.0 \\
\hline \multirow[t]{4}{*}{ Asset Guarantees } & Asset relief facility & 6.0 & & \\
\hline & Fortis SPV & 1.3 & & \\
\hline & Fortis portfolio & 0.4 & & \\
\hline & Total Asset Guarantees & 7.7 & & 7.7 \\
\hline \multicolumn{5}{|l|}{ Denmark } \\
\hline \multirow[t]{2}{*}{ Recapitalization } & Capital Assistance Program & 2.7 & & \\
\hline & Capital injection in Fionia Bank & 0.1 & & \\
\hline \multirow[t]{2}{*}{ Other } & Loan to Fionia Bank & 0.3 & & \\
\hline & Total Fiscal Outlays & 3.1 & & 3.1 \\
\hline \multicolumn{5}{|l|}{ France } \\
\hline \multirow[t]{3}{*}{ Recapitalization } & SPPE acquisition of subordinated bonds & 0.5 & & \\
\hline & Second stage recapitalization (BNP, SG, Dexia) & 0.5 & & \\
\hline & Total Fiscal Outlays & 1.0 & & 1.0 \\
\hline Asset Guarantees & Financial Security Assurance Inc. & 0.3 & & \\
\hline \multicolumn{5}{|l|}{ Germany } \\
\hline Recapitalization & Capital Injection Program & 1.2 & & 1.2 \\
\hline \multirow[t]{2}{*}{ Asset Purchases } & Asset purchase program & 0.2 & & \\
\hline & Total Fiscal Outlays & 1.4 & & 1.4 \\
\hline Asset Guarantees & Bad Bank Act ${ }^{2 /}$ & 6.1 & & \\
\hline \multicolumn{5}{|l|}{ Greece } \\
\hline Recapitalization & Capital injection package & 1.7 & & \\
\hline \multirow[t]{2}{*}{ Other } & Liquidity & 1.9 & & \\
\hline & Total Fiscal Outlays & 3.6 & & 3.6 \\
\hline \multicolumn{5}{|l|}{ Hungary } \\
\hline Recapitalization & Capital injection in FHB (mortgage lender) & 0.1 & & \\
\hline \multirow[t]{2}{*}{ Other } & FX loans to large banks & 2.6 & & \\
\hline & Total Fiscal Outlays & 2.7 & 1.6 & 1.1 \\
\hline \multicolumn{5}{|l|}{ Iceland $^{3 /}$} \\
\hline Recapitalization & Landsbanki, Kaupthing, and Islandsbanki & 13.0 & & 13.0 \\
\hline \multicolumn{5}{|l|}{ Ireland } \\
\hline Recapitalization & Bank of Ireland, Allied Irish Bank, and Anglo Irish & 7.6 & & 7.6 \\
\hline \multicolumn{5}{|l|}{ Kazakhstan } \\
\hline Recapitalization & BTA, Halyk, Alliance, and KKB & 2.4 & & \\
\hline \multirow[t]{2}{*}{ Other } & Liquidity through deposits of the development agency & 1.3 & & \\
\hline & Total Fiscal Outlays & 3.8 & & 3.8 \\
\hline \multicolumn{5}{|l|}{ Latvia } \\
\hline Recapitalization & Parex and MLBN & 2.5 & & \\
\hline Other & Liquidity & 2.5 & & \\
\hline & Total Fiscal Outlays & 4.9 & & 4.9 \\
\hline Luxembourg & & & & \\
\hline Recapitalization & Fortis and Dexia & 7.7 & & 7.7 \\
\hline
\end{tabular}




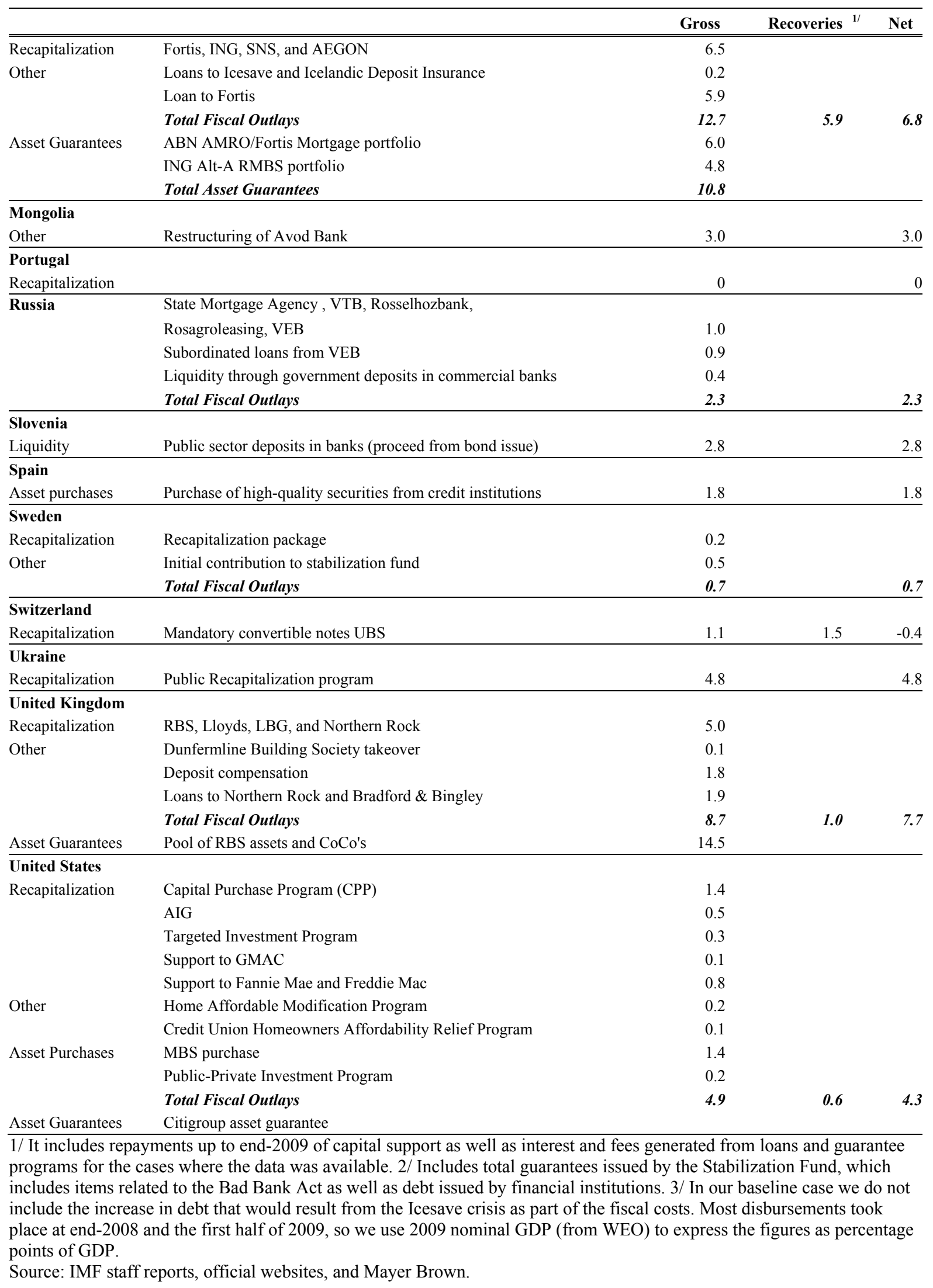


Table A.4. Top 30 Banks in the World By Market Capitalization

\begin{tabular}{|c|c|c|c|c|c|c|}
\hline & & \multicolumn{2}{|c|}{$\begin{array}{c}\text { Market } \\
\text { Capitalization } \\
\text { (millions of US\$) }\end{array}$} & & \multirow{2}{*}{$\begin{array}{c}\begin{array}{c}\text { Market } \\
\text { Capitalization } \\
\text { (millions of US\$) }\end{array} \\
2009 \\
\end{array}$} \\
\hline Bank name & Country & 2006 & 2009 & Bank name & Country & \\
\hline 1 Citigroup & $\overline{\mathrm{UUSA}}$ & 286,337 & $\overline{17,016}$ & 1 HSBC Holdings & UK & 199,785 \\
\hline 2 Bank of America & USA & 251,872 & 68,660 & 2 China Construction Bank & China & 193,240 \\
\hline 3 Mitsubishi UFJ Financial Group & Japan & 188,034 & 53,052 & 3 JP Morgan Chase & USA & 148,484 \\
\hline 4 HSBC Holdings & UK & 172,938 & 199,785 & 4 Banco Santander & Spain & 136,918 \\
\hline 5 JP Morgan Chase & USA & 172,109 & 148,484 & 5 Wells Fargo \& Co & USA & 112,251 \\
\hline $6 \mathrm{UBS}$ & Switzerland & 156,455 & 50,242 & 6 BNP Paribas & France & 95,359 \\
\hline 7 Banco Santander & Spain & 127,400 & 136,918 & 7 Goldman Sachs & USA & 69,454 \\
\hline 8 Wells Fargo \& Co & USA & 122,056 & 112,251 & 8 Ind'l \& Commercial Bank of China & China & 68,968 \\
\hline 9 Wachovia Corp & USA & 114,542 & Failed & 9 Banco Bilbao Vizcaya Argentaria & Spain & 68,733 \\
\hline 10 Mizuho Financial Group & Japan & 114,249 & 21,423 & 10 Bank of America & USA & 68,660 \\
\hline 11 BNP Paribas & France & 110,786 & 95,359 & 11 Royal Bank of Canada & Canada & 64,894 \\
\hline 12 ING Groep & Netherlands & 106,700 & 38,077 & 12 National Australia Bank & Australia & 56,732 \\
\hline 13 Royal Bank of Scotland & UK & 102,726 & 26,655 & 13 UniCredit & Italy & 56,538 \\
\hline 14 UniCredit & Italy & 99,639 & 56,538 & 14 Credit Suisse Group & Switzerland & 55,706 \\
\hline 15 Sumitomo Mitsui Financial & Japan & 98,384 & 27,429 & 15 Intesa Sanpaolo & Italy & 53,771 \\
\hline 16 Credit Suisse Group & Switzerland & 96,203 & 55,706 & 16 Mitsubishi UFJ Financial Group & Japan & 53,052 \\
\hline 17 Banco Bilbao Vizcaya Argentaria & Spain & 93,333 & 68,733 & 17 Société Générale & France & 52,169 \\
\hline 18 Goldman Sachs & USA & 91,457 & 69,454 & 18 Standard Chartered & UK & 51,268 \\
\hline 19 Société Générale & France & 85,410 & 52,169 & 19 Itau Unibanco Holdings & Brazil & 50,722 \\
\hline 20 Merrill Lynch \& Co & USA & 82,235 & Failed & 20 American Express & USA & 50,281 \\
\hline 21 Morgan Stanley & USA & 80,553 & 31,307 & 21 UBS & Switzerland & 50,242 \\
\hline 22 Deutsche Bank & Germany & 80,433 & 44,201 & 22 Barclays & UK & 49,295 \\
\hline 23 Barclays & UK & 76,734 & 49,295 & 23 Commonwealth Bank of Australia & Australia & 48,062 \\
\hline 24 American Express Company & USA & 75,285 & 50,281 & 24 Deutsche Bank & Germany & 44,201 \\
\hline 25 HBOS & UK & 69,158 & 6,138 & 25 Banco do Brasil & Brazil & 43,382 \\
\hline 26 US Bancorp & USA & 68,942 & 39,617 & 26 Bank of Nova Scotia & Canada & 43,190 \\
\hline 27 Crédit Agricole. & France & 68,723 & 41,302 & 27 Westpac Banking Corp & Australia & 43,137 \\
\hline 28 ABN Amro Holdings & Netherlands & 64,717 & Failed & 28 Australia and New Zealand Banking & Australia & 42,473 \\
\hline 29 Fortis & $\begin{array}{l}\text { Belgium/ } \\
\text { Netherlands }\end{array}$ & 60,674 & 8,886 & 29 Crédit Agricole & France & 41,302 \\
\hline \multirow[t]{2}{*}{30 Royal Bank of Canada } & Canada & 59,686 & 64,894 & 30 Nordea Bank & Sweden & 41,284 \\
\hline & Total & $3,377,767$ & $1,633,871$ & & Total & $2,153,554$ \\
\hline
\end{tabular}

Note: Shaded ranking positions on left list indicate banks no longer among the top thirty in 2009, while shaded ranking positions on right list indicate banks that entered the top 30 list in 2009.

Source: Bankscope. 